\title{
DEGRADATION OF THE CARTILAGE BY MONONUCLEAR CELLS IN THE COURSE OF OSSIFICATION
}

\author{
H. ČERNÝ \\ Department of Anatomy, Histology and Embryology, University \\ of Veterinary Science, 61242 Brno
}

Received November 24, 1982

\begin{abstract}
Černý H.: Degradation of the Cartilage by Mononuclear Cells in the Course of Ossification. Acta vet. Brno, 53, 1984: 3-17.
\end{abstract}

Morphology of the destructive phase of endochondral ossification was studied in the metaphyseal rim of the growth cartilage of the tuber coxae using 17 bovine individuals from $241 \mathrm{~d}$ fetal age to $3.5 \mathrm{yr}$. The material was routinely processed for electron microscopy.

Our attention was focused on the role of the mononuclear cell in the process of degradation of the cartilaginous model in the course of ontogenetic development.

The electron-microscopic picture showing the cellular effects on the mineralized ground substance revealed endothelial cells of the penetrating blood capillaries, pericapillary clastic cells and free macrophages of hematogenic origin interposed between the wall of blood capillaries and ground substance of the cartilage participating in this process in the course of capillary invasion. In cattle, mononuclear clastic cells play a major role in destruction of the cartilaginous model being located in the erosion line and in the osteoid zone.

In the course of ontogenetic development the numbers of the individual cell types are changing. Whereas in the prenatal period capillary resorption and activity of pericapillary cells prevail, in the postnatal period of ossification free blood macrophages form the majority of cells involved.

Attacking of the mineralized ground substance by mononuclear clastic cells results in its degradation consisting of solubilization, fragmentation, phagocytosis and combined resorption.

Degradation of the cartilaginous model connected with resorption of the ground substance is a complex process. It is the result of cells effect on the cartilage during which several mechanisms are operating simultaneously. The most effective mechanism of degradation is fragmentation resulting in substantial enlargement of the active surface.

Larger fragments undergo further fermentation. These fragments are solubilized from the periphery of the ground substance to the centre and the smallest fragments are phagocytized by the macrophages. The final effect of cellular activity is complete solubilization of the ground substance and its resorption from the pericapillary space.

Cattle, ontogenesis, ossification, degradation of the cartilage, resorption, mononuclear cell.

Effects exerted by mononuclear cells on mineralized cartilage matrix have received rather limited attention in literature.

As early as 1970 Irving and Heeley suggested that two different cell types participate in the osteoclastic resorption. Using an autoradiographic method with ${ }^{3} \mathrm{H}$-proline-labelling for organic structures they demonstrated that non-labelled inorganic material was phagocytized by osteoclasts whereas the labelled organic material was destroyed by mononuclear cells. These data seem to indicate that osteoclasts cannot destroy the organic matrix. 
It follows from these findings that the osteoclastic resorption is a two-phase process during which mineral substances are resorbed by osteoclasts without degradation of the organic substance. Both processes are clearly distinguished (Schofield et al. 1974).

Primary degradation of inorganic substance has been assumed in papers describing the two-phase resorption process (Irving and Heeley 1970; Schofield et al. 1974; Heersche 1978). On the other hand, in view of S cott and Pease (1956) and Dudley and Spiro (1961), the primary phase is that of the organic matrix degradation. In the opinion of Cameron and Robinson (1958) both organic and mineral components are attacked simultaneously.

The two-phase resorption theory with several cell types involved reoccurred with Heersche (1978). The osteoclastic resorption causes solubilization of the inorganic substance, degradation of the non-collagen structures and finally of collagen fibrils. Interestingly, in no case collagen fibrils have been detected in the contents of cytoplasmic vacuoles of the osteoclasts indicating that they are degraded extracellularly. Extracellular lysis of collagen has been often ascribed to cell elements with phagocytic properties. According to the theory by the above-mentioned author, two cell types participate in the process. The onset of resorption is initiated by osteoclasts causing demineralization of the resorptive zone and degradation of non-collagen components of the bone matrix. As soon as this is finished the osteoclast leaves the altered matrix by active movement and collagen fibrils are phagocytized by mononuclear cells, derivatives of fibroblasts or monocytes.

The above-mentioned description indicates that the osteoclastic resorption proper is composed of two clearly separated phases that are under precise endocrine control.

As shown by Rasmussen and Bordier (1974), the mononuclear cells are often located in close vicinity of osteoclasts. Mononuclear cells may be represented by macrophages (Horn 1979; Chambers 1981; Černý 1982) or fibroblast elements (Garant 1976).

Mundy et al. (1977) have shown that resorption of mineralized tissue exerts a chemotactic effect on monocytes. Macrophages and fibroblasts belong among the cell elements that are able to phagocytize and degrade collagen as demonstrated by findings of small vesicles in the cytoplasm of macrophages containg collagen.

Garant (1976) investigated the mutual relations between fibroblasts and osteoclasts in the course of bone resorption on electron-microscopic level. During resorption, conspicuous structural changes occur in the cytoplasm of the fibroblasts in close contact to an osteoclast. In the cell, collagen fibrils occur attached to lysosomes. This serves to demonstrate that collagen is phagocytized from the extracellular space by fibroblasts.

Other mononuclar cells capable to resorb the ground substance of the cartilage are the endothelial cells of the penetrating blood capillaries eroding the cartilage and enabling thus invasion of capillaries (Camer on 1961). Activity of endothelial cells and their role in solubilization of the cartilage in ossification has been also shown by Brookes and Landon (1964), Trueta and Little (1960) and Lester and Ash (1981).

As the population of clastic cells is composed of several cell types, the result of their activity the resorption takes place in several different forms. There is not a process uniform in character but a result of a complex, accurately regulated development. The review of relevant literature shows that the cells causing degradation of the mineralized cartilage matrix are not only multinuclear elements but also mononuclear cells like macrophages, endothelial cells and, finally, osteocytes the activity of which is sometimes called osteolysis (Bélanger 1969; Jande and Bélanger 1971, 1973; Horn 1979; Horn and Dvořák 1980).

\section{Materials and Methods}

Ossification was studied on metaphyseal rim of the growth cartilage from the tuber coxae of 6 bovine fetuses aged 246-271 d, 6 calves aged 65-82 d, and 5 adult cattle aged 3 and 3.5 years ( 3 individuals aged 3 years, 2 individuals aged 3.5 years).

The material was collected from 3 main sites: from the metaphyseal area of the growth cartilage, from the erosion line between the cartilage and bone, and from the osteoid zone ( 5 samples from each site).

For electron microscopic study the samples were fixed in $400 \mathrm{mmol} / 1$ glutaraldehyde in $100 \mathrm{mmol} / 1$ phosphate buffer, pH 7.4 for $4 \mathrm{~h}$, decalcified in $100 \mathrm{mmol} / 1 \mathrm{EDTA}$ with $400 \mathrm{mmol} / 1$ glutaraldehyde for $12-14 \mathrm{~h}$. The samples were then washed in four rinses of $100 \mathrm{mmol} / \mathrm{l}$ phosphate buffer, $\mathrm{pH} 7.4$ and postfixed with $40 \mathrm{mmol} / 1 \mathrm{OsO}^{4}$ in $100 \mathrm{mmol} / 1$ phosphate buffer, $\mathrm{pH} 7.4$ for $1 \mathrm{~h}$. After dehydration in graded acetone series the samples were embedded in Durcupan ACM and polymerized at $60^{\circ} \mathrm{C}$ for $3 \mathrm{~d}$. All procedures were carried out at room temperature.

Semithin and ultrathin sections were cut on an ultramicrotome Tesla BS 490 and Ultracut Reichert.

Ultrathin sections were double stained on supporting greeds (Mesh 100) using a combined method 
(uranyl acetate and lead citrate) after Reynolds and viewed and photographed with a Tesla BS 613 and BS 500 electron microscopes.

Semithin sections were stained with warm solutions of $1 \%$ methylene blue in $1 \%$ borax and

$1 \%$ aqueous solution of Azur II $1: 1$ for 1 minute.

Electron micrographs were made using ORWO - EU $26.5 \times 9 \mathrm{~cm}$ plates.

\section{Results}

\section{Resorption of the cartilaginous model}

Degradation of the ground substance of the cartilage occurs in the line of erosion and in the osteoid zone of endochondral ossification through chondroclastic activity of cells. The mineral matrix is attacked by cell elements causing lysis of the ground substance or often its fragmentation. The degradation proper is a result of remarkable phagocytic and resorptive activities of mononuclear and multinuclear clastic cells. Among mononuclear cells, the following participate in degradation of the ground substance of cartilage:

1. Endothelial cells of the penetrating blood capillaries

2. Mononuclear pericapillary cells (pericapillary macrophages)

3. Macrophages of hematogenic origin.

\section{Endothelial cells.}

The endothelial cells of sinusoid blood capillaries are interconnected by thin cytoplasmic projections. These vessels are characterized by impaired integrity of capillary wall resulting in disconnection of cytoplasmic projections of the endothelial cells. The blood plasma flows into pericapillar space where also free erythrocytes may be encountered.

As the sinusoid capillaries have no basement membrane the cytoplasmic membrane of endothelial cells on their basal surface is in direct contact with the mineralized ground substance of cartilage (Fig. 3, 4).

The endothelial cells have a ,relatively large oval nucleus situated centrally or eccentrically near to one cell pole. The nuclear chromatin is condensed near the nuclear envelope which is slightly waved in some cells (Fig. 3).

In cytoplasm of the endothelial cells inconspicuous areas composed of granular endoplasmic reticulum formed by flat cisterns may be seen (Fig. 3 and 4). Among these cisterns free ribosomes are present often as polysomes. Mitochondria are mostly round or oval and are irregularly disseminated in the cytoplasm.

Important organelles in the endothelial cell are numerous lysosomes of different densities indicating cell activity in destruction of the ground matrix (Fig. 3). Often phagosomes are the dominant finding in the cytoplasm. They are enveloped by a thin membrane and their contents are formed by finely granular moderately osmiophilic material and pseudomyelin structures (Fig. 4).

Near the luminal surface of the endothelial cell minute vesicles coated with a smooth membrane are present in the cytoplasm. The cytoplasmic membrane of the basement surface forms small cytoplasmic projections which are in direct contanct with the ground substance of cartilage.

At the site of contact of the endothelial cell with the ground matrix of the cartilage signs of attacking this substance by the endothelial cell are obvious.

Small cytoplasmic projections of the basal cell surface are in direct contact with 

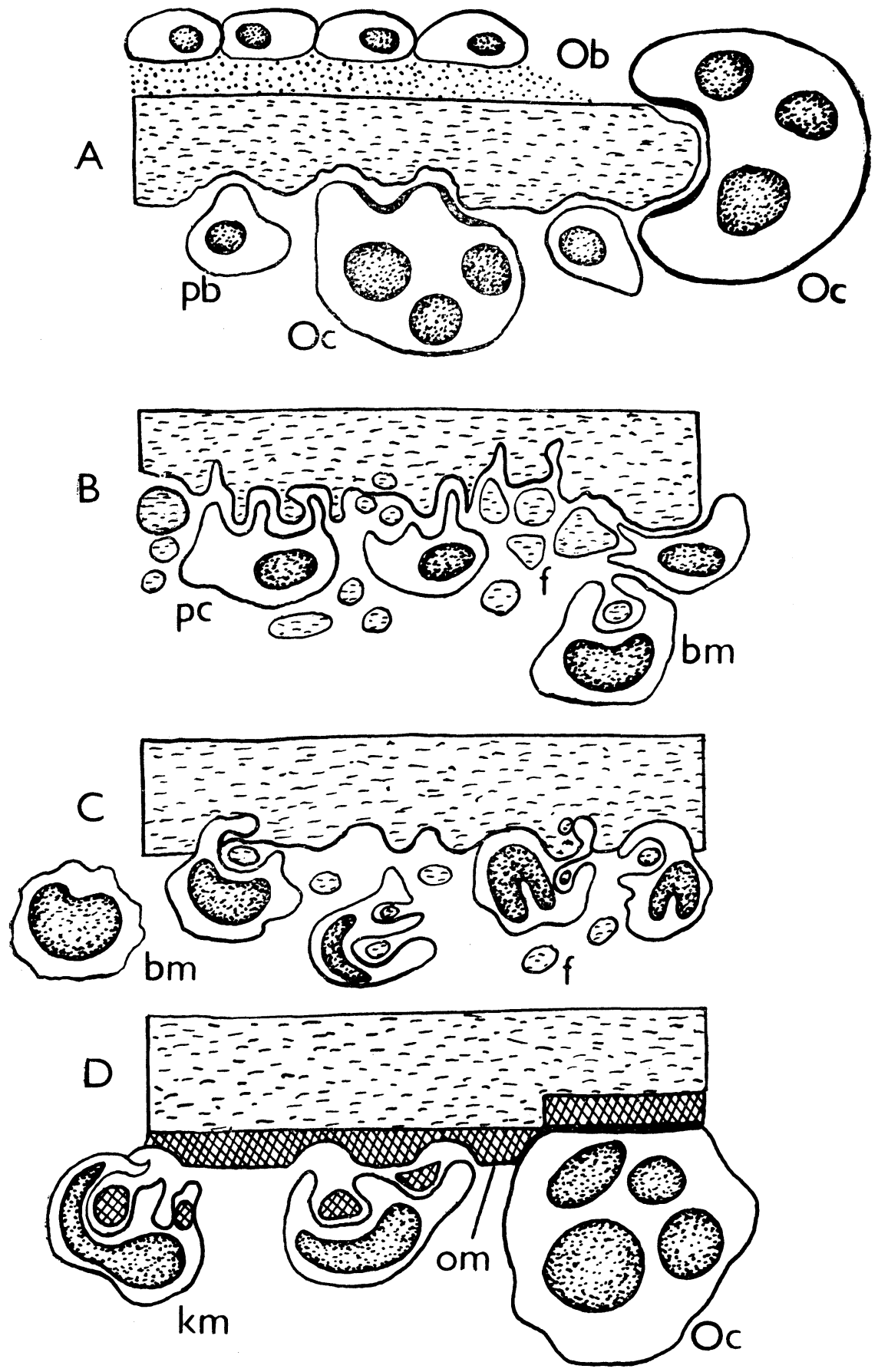
the matrix only in smaller areas. Formation of narrow intermediary spaces between the membrane and ground substance may be observed (Fig. 3). These spaces are electron-transparent or filled with material of similar density as blood plasma in capillary lumen. Through impaired capillary wall the blood plasma flows into the space between endothelial cells and the cartilaginous ground substance and forms here a suitable medium for the action of cell enzymes. At the contact site erosive activity of endothelial cells is clearly visible. They dissolve the ground substance which then undergoes conspicuous structural changes consisting of fenestration and decrease in the amount of its substance. In the ground substance, minute electron-transparent islets occur. Some of them contain granular and fibrillar material. Due to the resorptive cellular activity intermediary spaces are formed between the cytoplasmic membrane and the ground substance appearing at sites of former intimate contact of the cell with the mineralized matrix.

The resorptive margin of the ground substance is not lined with lamina limitans composed of organic substance of the ground matrix. This indicates that the endothelial cells attack both components of the ground substance of cartilage and destroy both inorganic and organic substances simultaneously.

\section{Pericapillary clastic cells}

An important role in chondroclastic destruction of the cartilaginous model in endochondral ossification of cattle in prenatal and postnatal periods is that of mononuclear pericapillary cellular elements. After destruction of the transverse septa they accompany blood capillaries into the lacunar spaces and destroy the ground substance of cartilage and the disintegrated hypertrophied chondrocytes.

In interposition between capillaries and the ground matrix of cartilage there is abundant cellular material formed by mitotic activity of cells in pericapillary space (Fig. 1). The pericapillary cellular elements arise above all through further differentiation of less differentiated cells whose progenitors are the mesenchymal cells. This fact is supported by frequently found mesenchymal cells in pericapillary spaces in the osteoid zone of ossification. Together with penetrating blood vessels they pass proximally towards lacunae and gradually differentiate into clastic and blastic cell elements (Fig. 2).

The progenitor cells of the clastic mononuclear pericapillary cells are long, slim cells apposed to the surface of the ground substance of the cartilage, designated as preosteoclasts. Their round nucleus is usually located near one of the cell poles. The nucleus contains mostly two nucleoli of reticular type. The cytoplasmic membrane of the slim preosteoclast forms relatively short, conical projections directed toward the ground substance. The cytoplasm is basophilic due to considerable number of free ribosomes and polysomes.

Cell organelles and their differentiation show that the cell is less differentiated, however, in contrast to the mesenchymal cell, it contains numerous lysosomes of various sizes and contents. Lysosomes and small vesicles of the Golgi complex may be mainly seen in the perinuclear area of the cell.

Scheme of degradation of the mineralized cartilage ground substance in the course of ossification $\mathrm{A}$ - resorption, $\mathrm{B}$ - fragmentation, $\mathrm{C}-$ phagocytosis, $\mathrm{D}$ - resorption of the inorganic substance with subsequent phagocytosis of the organic matrix, Oc - osteoclast, $\mathrm{Ob}$ - osteoblast, pc - pericapillary mononuclear cell, bm - blood macrophage, $f$ - fragment of the ground substance, om organic matrix. 
The presence of lysosomes in the cytoplasm of preosteoclast and the structural picture of the ground substance at sites of contact indicates that attacking of the mineralized ground substance of cartilage and the preosteoclast play an active role in the chondroclastic destruction of cartilage. Enzymatic destruction is shown by lysis of the ground substance.

Apart from preosteoclasts, in pericapillary space differentiated pericapillary mononuclear cells exhibiting a remarkable clastic activity are present. Mononuclear chondroclasts degrade the mineralized ground substance of the cartilage by enzymatic degradation, fragmentation and phagocytosis.

Clastic pericapillary cells (pericapillary macrophages) play a paramount role in degradation of the ground substance of the cartilaginous model in cattle. They may be seen in the erosion line where they accompany blood capillaries and together with them they invade the degenerated cartilage.Together with the endothelial cells they participate in destruction of the transverse and longitudinal septa of the ground substance of cartilage. After penetration into the lacunae they destroy the lacunar area of the cartilage. In the erosion line they are interposed between the capillary tips and ground substance and form the erosion front. After a breakthrough of the last transverse septum they become the contents of open lacunae together with free erythrocytes, blood plasma and disintegrated structures of hypertrophied chondrocyte.

In the osteoid zone, clastic mononuclear cells appose to the surface of ground substance trabeculae. In majority of cases a direct contact of the cytoplasmic membrane with the ground matrix is formed. However, a narrow space filled with plasma may be formed. The narrow extracellular space is often filled with free erythrocytes placed between the cell surface and cartilage trabeculae.

Mononuclear clastic elements have phagocytic properties (Fig. 5) and, from the functional point of view, we include them among macrophages.

As the cytoplasmic membrane forms numerous projections, the shapes of these cells are extremely variable.

After penetrating into the lacuna, the long cytoplasmic projections pass in parallel with the trabeculae of the ground substance, often accompanied by free erythrocytes. The blood plasma fills the lacunar space, forms the medium surrounding the cell and the ground substance of the cartilage. In close vicinity of projections small fragments of mineralized matrix and pseudomyelin structures may be seen (Fig. 5). Some of the cytoplasmic projections of the pericapillary macrophages form minute secondary plasmatic pseudopodia protruding into the ground substance. They segregate small particles from the trabecular surface and lacunar walls and phagocytize them into the cytoplasm of the projections. Therefore in the cytoplasm of these projections numerous phagosomes of different sizes and shapes may be detected as well as minute phagocytized fragments of the ground substance (Fig. 5). Cytoplasm of the cell projections contains numerous filaments oriented along the longitudinal axis of the projection and supporting its cytoplasm (Fig. 6). Among cell organelles, most frequently lysosomes in form of dense bodies of various sizes are present. The cytoplasm further contains free ribosomes, mitochondria and vacuoles of various shapes filled with moderately osmiophilic material.

In the cell cytoplasm a rather large portion is occupied by an oval nucleus. Its nuclear envelope is smooth or slightly waved. The nuclear envelope of these cells never formed deep invaginations. Clusters of heterochromatin are dispersed in the nucleus but tend to condense near the nuclear membrane. Inside the nucleus 
usually one or two nucleoli of reticular type are present; less frequently compact nucleoli may be encountered.

In the perinuclear area the well developed Golgi complex is present. It is formed from the flat cisterns arranged in parallel and surrounded by a smooth membrane. A conspicuous structure of the Golgi complex are the small vesicles coated by a smooth membrane, scattered among cisterns and forming rather large Golgi fields (Fig. 7).

Among the Golgi complex structures minute cisterns of granular endoplasmic reticulum are visible. They pass the central part of the cell cytoplasm. Towards the cytoplasmic membrane they tend to dilate slightly. Among the cisterns, free ribosomes and numerous polysomes reaching the cortical layer of cytoplasm may be found. The cortical layer does not contain other organelles except for free ribosomes, polysomes, dense bodies and singular cisterns of the granular endoplasmic reticulum. The cortical granular cytoplasm turns into cytoplasm of cellular projections (Fig. 7).

Mitochondria are irregularly scattered in the cytoplasm and they vary considerably in size and shape. They often reach the cytoplasm of cellular projections. Their centres appear frequently electron-transparent. The determinant structures of pericapillar macrophages are numerous lysosomes and dense bodies with conspicuous central condensation of the dense substance (Fig. 8). Lysosomes and dense bodies exhibit a considerable variability in shape, size and osmiophilic properties of the substance. These structures are most frequent in cytoplasm of the cellular projections attacking the ground substance of the cartilage.

Electron micrographs showing the clastic elements in the erosion line and in the osteoid zone of ossification indicate that no intimate contact of the cytoplasmic membrane and the cartilage is necessary for degradation of the ground substance. The cellular enzymes are excreted by the pericapillary macrophages into the space between the membrane and the ground substance which is thus gradually destroyed. Degradation is morphologically indicated by dissolving or fragmentation of the ground substance. In the extracellular space interposed between the cytoplasmic membrane and ground substance, often minute vesicles coated by a smooth membrane are visible. Their contents often leave the cell (Fig. 8).

\section{Free macrophages of hematogenic origin}

Functionally and morphologically important group of cells with conspicuous phagocytic properties are the free macrophages of hematogenic origin. They participate in phagocytosis of the ground substance of the cartilaginous model. They phagocytize small fragments of the cartilage in pericapillary space or they actively attack the ground substance of the cartilage, fragment it and phagocytize its particles. They occur particularly in the erosion line and in the osteoid zone of endochondral ossification.

After leaving the vascular bed, the macrophage assumes a slightly oval shape, the cytoplasmic membrane forms small, inconspicuous projections. Remarkably large, light nucleus fills a considerable portion of the cytoplasm. It is mostly kidney-shaped with slightly waved nuclear envelope and invaginations only suggested. The nucleus is poor in chromatin and contains a few smaller, mostly compact nucleoli. Between the nucleus and cytoplasmic membrane a relatively narrow perinuclear space is formed. In the cytoplasm, oval or slightly elongated 
mitochondria are present along with minute vesicles arranged in several areas, larger vacuoles, granules and phagosomes.

After invading the pericapillary space in which free macrophages are present in groups or as individual cells surrounded by erythrocytes and cellular pericapillary material they approach the ground substance of the cartilage.

Attacking of the cartilage by macrophages begins as soon as in the first phase, i. e. cell adhesion. Between the trabecular surface and cytoplasmic membrane small particles of ground substance occur, and in their vicinity moderately osmiophilic finely granular material of fibrillar material occurs as a product of the enzymatic action upon the substrate (Fig. 11).

Due to the phagocytic activity of free macrophages the cytoplasmic membrane forms small thin projections of plasmatic pseudopodia. The overall cell shape is thus changing considerably and it differs from that found in macrophages immediately after their migration from the vascular bed.

Plasmatic pseudopodia penetrate into the ground substance, segregate small fragments from the trabecular surface. Through cytoplasmic connection of pseudopodia the fragments receive a smooth membrane before they are phagocytized into the cell (Fig. 12).

Pseudopodia of the cytoplasmic membrane occur also on the cell surface which is not in contact with the ground substance.

The cell centre is occupied by a large nucleus whose nuclear envelope is slightly waved and forms conspicuous invaginations. In older cells, the nucleus is segmented and the individual segments are interconnected by nuclear bridges (Fig. 14). Heterochromatin lumps are dispersed in nucleoplasm with more expressed condensation of heterochromatin near the nuclear envelope. In the nucleoplasm, usually one nucleolus of the reticular or compact type is present.

In perinuclear cytoplasm, near the nuclear invagination, the Golgi complex is situated (Fig. 12). In some cells it surrounds completely the nucleus and forms conspicuous Golgi fields. The Golgi complex consists of parallel elongated cisterns coated with a smooth membrane and vesicles of various sizes. Minute vesicles covered with a smooth membrane and moderately dense material are mostly located in the perinuclear area of the cytoplasm together with cisterns; larger vesicles that can already be designated as smaller vacuoles, present on the other hand, are in the peripheral cytoplasm. Some vacuoles contain dark material, others are electron-transparent.

Macrophages phagocytize also intracellular material smaller fibrils and proteinpolysaccharide grains become the contents of phagosomes.

Mitochondria are relatively large, round or slightly elongated, their centres are often electron-transparent.

In the cytoplasm of free blood macrophages numerous lysosomes are present varying in shape and size. In close vicinity of the Golgi complex small vesicles may be observed the sizes of which become the larger the nearer they are to the cytoplasmic membrane. In several cells, however, in close contact with cisterns of the Golgi complex, also larger lysosomes are visible. They contain material of various densities, enveloped by a smooth membrane.

An inconspicuous cell organella is the granular endoplasmic reticulum forming individual cisterns or minute tubulovesicular structures. Free ribosomes and polysomes are present, too.

From the cellular surface numerous pseudopodia are projecting. Their cytoplasm has granular appearance and contains no conspicuous organelles. Only 
free ribosomes or polysomes and minute vesicular structures are the organelles present in pseudopodia (Fig. 12). The morphological picture of cytoplasmic pseudopodia suggests their function connected with the movement of the cell during attacking of the ground substance. Pseudopodia differ in shapes and they are adapted to the phagocytic activity of the cell (Fig. 13). Characteristic are large phagosomes in the cytoplasm of free macrophages. Macrophages phagocytize small fragments of the ground substance of cartilage (Fig. 14). Some phagosomes contain granular, moderately osmiophilic material with subcellular membrane structures of granular endoplasmic reticulum of the disintegrated hypertrophied chondrocytes. This picture may be encountered mostly in macrophages invading the lacunar spaces after destruction of the transverse septa (Fig. 15 and 16).

Large phagosomes are often located near the nucleus, at the site of a deep invagination of nuclear envelope as shown in Fig. 14.

Mononuclear clastic elements including free blood macrophages are of paramount importance in resorption of the cartilaginous model in endochondral ossification in cattle during both the prenatal and postnatal development. Free blood macrophages are particularly important in postnatal ossification. As shown in Fig. 15 and 16, they penetrate the lacunar space, get in cytoplasmic contact with the hypertrophied chondrocyte and participate in its phagocytosis including non-cellular intralacunar material. Therefore, in the cytoplasm of macrophages phagosomes with various contents may be observed. Macrophages phagocytize fine collagenous fibrils and dense granules, frequently found in lacunar contents. Action of macrophages upon the ground substance results in its fragmentation, dissolution of the inorganic substance (Fig. 17 and 18), disintegration of collagenous fibrils and their phagocytosis (Fig. 19 and 20).

Older phagosomes contain pseudomyelin structures resulting from cellular activity.

\section{Interaction between the cell and the mineralized matrix}

Effects of the free macrophages upon mineralized ground substance of the cartilage makes itself felt as soon as during adhesion of the cell to its surface (Fig. 11). Enzymatic activity results in degradation of the ground substance, often with formation of small fragments that later undergo phagocytosis. In another case (Fig. 12 and 13), active penetration of plasmatic pseudopodia into the ground substance may be encountered. Blood plasma becomes the tissue medium of macrophages in the lacunar space or in pericapillary space of the osteoid zone of ossification. Blood plasma also serves the transport of organic matrix and so enables its phagocytosis even if the macrophage is not in direct contact with the cartilage ground substance (Fig. 15). Blood plasma as tissue medium is often interposed between the cytoplasmic membrane and trabecular surface.

Important role of free macrophages is that played in destruction of cellular elements. This destruction is accompanied by conspicuous structure disintegration of these elements. Subcellular structures of hypertrophied chondrocytes in lacunar space are further disintegrated and phagocytized by free macrophages. By action of these clastic elements the ground substance of the cartilage and lacunar cell debris is degraded. Likewise, noncellular intralacunar contents are phagocytized by free blood macrophages as evident from their intracellular occurrence in the cytoplasm of macrophages. 
By resorption of the cartilage ground substance complete degradation of some longitudinal septa occurs with partial desctruction of transverse septa and phagocytosis of lacunar contents. Thus the intertrabecular spaces between the indivudal trabeculae become larger, and longitudinal enlargement of these spaces by interconnection of lacunae follows. The action of clastic mononuclear cellular elements forms the space necessary for the activity of osteoblastic cells during the osteogenic phase proper.

The clastic and blastic functional interdependence is documented in Fig. 15: the direct contact and attacking of the hypertrophied chondrocyte by a free blood macrophage, the clastic activity of the pericapillary cell cemonstrated by dissolution and fragmentation of the ground substance, and, finally, an active secreting osteoblast $(\mathrm{Ob})$ starting to appose the osteoid matrix to the trabecular surface. Differentiating collagenous fibrils interposed between the cell and trabecular surface are clearly visible. They present the organic remains of the transverse septum.

This morphological picture shows the functional and time dependence of both complex processes in the course of endochondral ossification, the clastic and formative phases. By functional specialization involved in degradation and phagocytosis of the ground mineralized matrix gradual differentiation of endowment of macrophages with organelles occurs. The ultrastructural picture of young cells in the lacunar space or in pericapillar spaces is morphologically simpler as compared to the functionally active macrophages.

\section{Ultrastructural differentiation of mononuclear cells}

Blood macrophages may be distinguished from pericapillary mononuclear clastic elements. Free blood macrophages have a large nucleus with characteristic deep invaginations of the nuclear envelope. The nucleus of these cells is often segmented and in the electron-microscopic field the individual segments are separated or connected by nuclear substance. In general, it can be stated that the nucleus is located in the centre unlike that of the pericapillary clastic cells in which it often lies eccentrically near the cell pole.

The nucleus of pericapillary cells is round or slightly oval with mildly waved nuclear envelope rather than conspicuous invaginations. In the cytoplasm of free macrophages the Golgi complex is a prominent structure. It forms distinct, in some cases circumnuclearly oriented cisterns and vesicles. With the Golgi complex in pericapillary cells minute vesicular structures prevail.

In young free blood macrophages the granular endoplasmic reticulum is present in small amounts and in the form of flat cisterns and vesicular structures enclosed by a granular membrane. In older, functionally active cells the structures of the granular endoplasmic reticulum increase in number and the cisterns dilate. Granular endoplasmic reticulum is in these cells, however, much less abundant than in the pericapillary cells.

Another characteristic ultrastructural feature of the pericapillary clastic elements is the formation of long, fibrillar cytoplasmic projection. The cytoplasm in these projections is finely granular and contains some organelles.

Plasmatic pseudopodia of free macrophages are shorter and often form secondary, small pseudopodia on the surface of the basic projection. The cytoplasm of pseudopodia has granular appearance and usually contains no organelles.

Conspicuous presence of granular endoplasmic reticulum in the cytoplasm of pericapillary clastic cells indicates further possible functions of these cells. 


\section{Discussion}

Resorption of the cartilaginous model is an integral part of the complex ossification process without which this model could not be gradually replaced by bone tissue. In the destructive phase of ossification the vast area of mineralized tissue must be degraded except for the remaining directional trabeculae serving to support the formation of primary bone tissue in the osteogenic phase of ossification.

Interaction of the cells and ground substance results in destruction of the ground mineralized substance of the cartilage.

The cells causing chondroclasia are designated as clastic elements and they appear as mononuclear or multinuclear cells. In cattle dominant role in cartilage resorption is played by mononuclear cells. These comprise endothelial cells from the vascular walls of blood capillaries, mononuclear pericapillary cells and free macrophages. Multinuclear cells are present in small numbers as compared to the mononuclear ones.

Multinuclear cells are formed in areas characterized by intensive resorption of the mineralized matrix. This results in impaired local mineral homeostasis; the resorbed matrix cannot be disposed of by humoral ways. Therefore the multinuclear cell becomes involved and transports the resorbed substances across the cell from its resorptive pole to its basal pole and further into blood vessels.

Until recently the multinuclear cell had been regarded as the single cell type capable of resorption. At present, the role of mononuclear cells in this process has been much discussed. These cells, in our opinion, are of great functional importance in the process.

Destruction of the cartilaginous model has been described in literature as resorption. However, this process is functionally much more complex and resorption is the final phase of cartilage destruction.

The cartilage attacked by mononuclear or multinuclear cells is further degraded in the course of ossification at the following levels:

1) Solubilization of the inorganic substance.

2) Fragmentation of originally compact cartilage.

3) Phagocytosis of the fragments of the ground substance.

4) Phagocytosis of the organic matrix of the cartilage occurring after preceding solubilization of the inorganic and non-collagenous substances.

It is obvious that resorption is a functionally complex process in the course of which several mechanism are operating at the same time.

Direct contact of the cell and cartilage ground matrix is not a prerequisite for the action of the cell. Degradation of the cartilage also proceeds with a narrow intermediary space between the cytoplasm and cartilage surface. This indicates that the prevailing portion of the cartilage is being destroyed by its solubilization as pointed out by Lester and Ash (1981). Solubilization of the ground substance takes place with vessel resorption by action of the endothelial cells but also in case of cellular resorption by clastic elements of the pericapillary space. Their cytoplasmic projection penetrate the cartilage, dissolve it ans cause its fragmentation. Cytoplasm of these projections contains numerous lysosomes, phagosome and polysomes. In some cases we observed the presence of nuclear mass in the cytoplasmic projections, a finding described also by Horn and Dvořák (1980). The cells of this type are able to phagocytize small fragments of the cartilage 
ground substance. Among other cells exhibiting the clastic effect on the cartilage and causing its fragmentation are free blood macrophages acting above all during the postnatal phases of ossification. Nevertheless, their role in fetal ossification is important. After adhering to the cartilage they attack the ground substance by small plasmatic pseudopodia, cause its fragmentation and phagocytize the individual fragments. These contain both organic and inorganic substance of the mineralized cartilage and they become the contents of numerous phagosomes in the cytoplasm of macrophages.

Smaller fragments are phagocytized directly, the larger ones are liberated into the pericapillary space where they are further attacked by clastic cells. The fragments are either solubilized from the surface towards the centre by enzyme activity or fragmented into smaller units. They are completely removed from the pericapillary space by total solubilization or phagocytosis.

The ultrastructure of clastic mononuclear elements present in the pericapillary space enables their exact discrimination.

An important discriminating sign is the shape of the nucleus. That of the pericapillary cells is round, the nuclear envelope is straight or only slightly waved and does not form invaginations. On the contrary, the nucleus of a macrophage of hematogenic origin is characterized by deep invaginations of the nuclear envelope. The endowment with organelles differs considerably in these two cell types. Pericapillary cells contain a well developed granular endoplasmic reticulum, the Golgi complex occupies a considerable portion of perinuclear area and mostly consists of vesicular structures of various sizes.

On the other hand, macrophages contain only single cisterns of the granular endoplasmic reticulum. The Golgi complex consists of in parallel coursing thin cisterns, sometimes forming large circumnuclear Golgi fields. The cytoplasm contains vesicles of various sizes enclosed by smooth membranes with contents of various electron densities. Many vesicles appear electron-empty.

Both cell types are well endowed with lysosomes. In the cytoplasm of pericapillar clastic cell dense bodies containing dense material with central condensation are prominent.

The last type of cartilage resorption observed in our electron-microscopic study of the osteoid zone was phagocytosis of the organic matrix proper. By solubilization of the inorganic and non-collagenous components of the cartilage, the dense lamina limitans appears on the surface of trabeculae (Scherft 1977; Smith et al. 1974). It is composed of uniform collagen fibrils with conspicuous transverse periodicity. This type of resorption comprises two distinct phases; in the first phase, by cellular action the inorganic substance is destroyed. In the second, the collagen fibrils are phagocytized by macrophages.

A new hypothesis of osteoclastic resorption has been presented by Heersche (1978) describing the sequence of processes as follows: solubilization of the inorganic substance, degradation of non-collagen structures, and, finally, resorption of collagen fibres. In this type of resorption two cell types participate. The process is initiated by osteoclasts resorbing the inorganic and non-collagen substances. Collagen fibrils are phagocytized by mononuclear cells originating from fibroblasts or monocytes. Heersche (1978) finds support in the fact that no collagen fibrils have been detected in the contents of cytoplasmic vacuoles of the osteoclast. This seems to indicate that collagen fibrils undergo degradation extracellularly through a different cell type. In our material this type of resorption was observed in the osteoid zone of cartilage. Apart from separated collagen fibrils we often 
found also minute fragments of the ground substance in their close vicinity. This findings serve to demonstrate clearly several types of destruction acting simultaneously. Nevertheless, the combined type of cartilage resorption is not very frequent as compared to solubilization, fragmentation and phagocytosis.

In the course of ossification a large amount of mineralized ground substance must be degraded. We observed fragmentation to be one of the most frequent modes of cellular action upon the cartilage ground substance enabling an intensive destruction of the cartilaginous model. Fragments separated from the originally compact cartilage, liberated into the pericapillary space enlarge considerably the overall active surface of the cartilage upon which then the clastic cells exert their effects. Enlargement of the overall active surface of the cartilage is accompanied by increased resorptive activity.

Although solubilization of the cartilage ground substance is the main mode of its degradation, phagocytic activity of the cells is important, too. A considerable amount of cartilage is destroyed by phagocytic activity of macrophages.

Intensity of the process in the destructive phase is dependent upon interaction of cellular elements and mineralized matrix. Fragmentation is one of the most efficient mechanisms determining the intensity of degradation of the cartilage. Efficient action of other mechanisms on these fragments results in complete removal of the cartilage from the pericapillary space.

\section{Degradace chrupavky mononukleární buňkou v osifikaci}

Na metafysárním okraji růstové chrupavky kyčelního hrbolu u skotu jsme u 17 jedinců ve věku 241 dní fetálního věku až do stáří 3,5 roku sledovali v obraze elektronového mikroskopu morfologický obraz destruktivní fáze enchondrální osifikace. Materiál byl zpracován obvyklým způsobem pro potřebu elektronové mikroskopie.

Zaměřili jsme se především na úlohu mononukleární buňky v procesu degradace chrupavčitého modelu $\mathrm{z}$ hlediska ontogenetického vývoje.

Elektronově mikroskopický obraz zachycující celulární pưsobení na základní mineralizovanou matrix ukázal, že na tomto procesu se podílejí v prüběhu kapilární invaze endotelové buňky penetrujících krevních kapilár, perikapilární klastické buňky a volné makrofágy hematogenního původu, nacházející se $\mathrm{v}$ interposici mezi stěnou krevních kapilár a základní hmotou chrupavky. U skotu mají mononukleární klastické buňky predominantní význam pro destrukci chrupavčitého modelu a topograficky se uplatňují v linii erose a $\mathrm{v}$ osteoidní zóně.

$\mathrm{V}$ průběhu ontogenetického vývoje se zastoupení jednotlivých typů buněk mění. Jestliže $\mathrm{v}$ prenatálním období převládá kapilární resorpce spolu s působením perikapilárních buněk, pak $\mathrm{v}$ období postnatální osifikace nabývají převahu volné makrofágy krevní.

Atakováním základní mineralizované matrix mononukleárními buňkami klastického typu dochází k její degradaci na těchto úrovních: solubilizací, fragmentací, fagocytosou a kombinovanou resorpcí.

Degradace chrupavčitého modelu spojená s resorpcí základní matrix je složitý proces, který je výsledkem buněčného působení na chrupavku, $v$ jehož průběhu se uplatňuje více mechanismů současně. Nejúčinnějším mechanismem degradace je fragmentace, která má za následek výrazné zvětšení aktivního povrchu.

Rozměrnější fragmenty jsou opětovně fragmentovány na menší, přičemž po- 
zorujeme současně solubilizaci základní hmoty od povrchu $\mathrm{k}$ centru, nejmenší fragmenty jsou fagocytovány makrofágy. Konečným efektem buněčného pưsobení na základní matrix je její úplná solubilizace a resorpce z perikapilárního prostoru.

\section{Деградация хряща одноядерной клеткой в оссификации}

На метафизарном крае ростового хряща маклока у крупного рогатого скота у 17 животных - 241 сутки зародышевого возраста до 3,5 года нами проводились исследования в изображении электронного микроскопа морфологической картины деструктивной фазы әнхондральной оссификации. Материал обрабатывали обычным способом для потребностей электронной микроскопии.

Внимание было направлено прежде всего на роль одноядерной клетки в процессе деградации хрящеватой модели с точки зрения онтогенегического развития.

Электронно-микроскопическое изображение, отражающее клеточное воздействие на основной минерализованный ростковый слой, показалю, что в данном процессе в ходе капиллярной инвазии принимают участие эндотелиальные клетки пенетрирующих кровеносных капилляр, перикапиллярные кластические клетки и свободные макрофаги гематогенного происхождения, находящиеся в интерпозиции между стенкой кровеносных капилляр пт основной массой хряща. Одноядерные кластические клетки у крупного рогатого скота имеют преобладающее значение для деструкции хрящеватой модели и топографически имеют место в линии эрозии и в остеоидной зоне.

В ходе онгогенетического развития представительство отдельных типов клеток меняется. Если преобладающей в пренатальный период является капиллярная резорбция совместно с воздействием перикапиллярных клеток, то в постнатальный период оссификации преобладающими становятся свободные макрофаги крови.

Атакой основной минерализованной ростковой зоны одноядерными клетками кластического типа происходит ее деградация на следующих уровнжх: коллоидным растворением, фрагментацией, фагоцитозом и комбинированной резорбцией.

Деградация хрящеватой модели, связанная с резорбцией основной ростков.й зоны является сложным процессом в результате клеточного воздействия на хрящ, в течение которого имеег место одновременное воздействие нескольких механизмов. Самым эффекгивным механизмом деградации является фрагментация, выливающаяся в выразительное увеличение активной поверхности.

Более размерные фрагменты вновь фрагментируются на более мелкие, при этом одновременно наблюдается коллоидное растворение основной массы от поверхности к центру, самые маленькие фрагменты фагоцитированы макрофагами. Конечным эффектом клеточного воздействия на основную ростковую зону является ее полное растворение и резорбция из перикапиллярного пространства. 
Fig. 1. With invasion of capillaries cells inhabiting wide pericapillary space penetrate into the cartilage. Between the cells numerous free erythrocytes (e) may be seen; some of them together with blood plasma fill the lacunae. Clastic mononuclear cells are represented by pericapillary cells (Pc) and free blood macrophages (Mf) inhabiting the space between the blood vessels (bc) and ground substance (gs). Fetus, $271 \mathrm{~d}$, semithin section, $\times 650$.

Fig. 2. Topography of cellular elements apposed to the surface of a directional trabecula. In the upper portion of the electron micrograph clastic mononuclear cells $(\mathrm{Oc})$ are resorbing the surface of the ground substance trabecula (gs). An osteoblastic cell (Ob) with abundant granular endoplasmic reticulum (E) the cisterns of which contain more dense synthesized material, is apposed to the bottom margin of the trabecula. On the right of the osteoblast, a differentiating pericapillary cell (Pc) is visible, on the extreme right, endothelial cell $(\mathrm{Ec})$ of the capillary wall with erythrocytes (e). Calf, $82 \mathrm{~d}, \times 12700$.

Fig. 3. In degradation of the ground substance (gs) of the cartilage endothelial cells participate. Their basal margin is in direct contact with the ground matrix. At their luminal aspect erythrocytes (e) are present. The slightly oval nucleus $(\mathrm{N})$ is located centrally; in the cytoplasm mitochondria are present $(M)$, further cisterns of the granular endoplasmic reticulum $(E)$, free ribosomes in the form of polysomes (P) and conspicuous lysosomes (L). The morphological picture of the ground substance (gs) indicates a remarkable degradation of its structure.

Calf, $82 \mathrm{~d}, \times 25000$.

Fig. 4. The relationship of the cytoplasmic membrane of the basement margin of the endothelial cell and the ground substance of the cartilage (gs) is either direct or through the intermediary space (Is) which may be filled with finely granular, moderately osmiophilic material. The same material forms the contents of larger phagosomes $(\mathrm{Ph})$ in the cytoplasm of the endothelial cell. In some phagosomes pseudomyelin structures $(\leftarrow)$ may be observed. The endowment with organelles is accomplished by mitochondria (M), granular endoplasmic reticulum (E), lysosomes (L) and polysomes $(\mathbf{P})$. Near the basal margin minute vesicular structures are conspicuous $(\mathrm{v})$.

Calf, 82 d, $\times 35000$.

Fig. 5. Pericapillary cells fragmenting the ground substance (gs) of the cartilage by their cytoplasmic projections (cp). In the lacunar space (lc) also subcellular fractions $(\leftarrow)$ may be encountered. They are remains after a total disintegration of chondrocyte structures. Frequently also pseudomyelin structures may be seen $(\leftarrow)$. The cytoplasm contains numerous large phagosomes $(\mathrm{Ph})$. Free erythrocytes (e) together with cells enter the lacunar space (1c).

Fetus, $246 \mathrm{~d}, \times 98000$.

Fig. 6. Cytoplasmic projections coursing in all directions in the lacunar space (1c) form a meshwork. The electron micrograph shows a longitudinal and transverse sections of a projection (cp). The cytoplasm of the projection contains numerous lysosomes (L), free ribosomes in the form of polysomes $(P)$ and less clear filaments. Fetus, $246 \mathrm{~d} \times 21400$.

Fig. 7. An osteoprogenitor cell with clastic function causing solubilization and fragmentation of the ground substance (gs) of the cartilage. At the site of apposition to trabecular surface, cytoplasmic projections (cp) may be seen. Their cytoplasm contains dense granules $(\leftarrow)$. Eccentric nucleus $(\mathrm{N})$ contains 2 nucleoli (nc). In the cytoplasm, rich Golgi complex (G), granular endoplasmic reticulum $(\mathrm{E})$, mitochondria $(M)$ and dense granules are present.

Fetus, $246 \mathrm{~d}, \times 8500$.

Fig. 8. Cellular activity results in degradation of the cartilaginous model in the osteoid zone. A mononuclear clastic cell causes solubilization and fragmentation of the ground substance (gs). Cytoplasmic projections $(\mathrm{cp})$ are attacking the ground substance. Besides the above-mentioned organelles the cytoplasm contains conspicuous dense bodies $(\mathrm{db})$ with a darker centre $(\leftarrow)$. In the extracellular space, minute vesicles (v) enveloped by a smooth membrane are visible. They contain moderately osmiophilic material.

Fetus, $246 \mathrm{~d}, \times 20000$.

Fig. 9. Free blood macrophages (Mf) participate in degradation of the cartilaginous model. They are present in the intercellular space of the osteoid zone together with free erythrocytes (e). Calf, $265 \mathrm{~d}, \times 3700$.

Fig. 10. Beginning adhesion of a free macrophage (Mf) to the surface of a trabecula of the ground substance (gs) of the cartilage. In close vicinity free erythrocytes (e) may be seen. Calf, $65 \mathrm{~d}, \times 9000$.

Fig. 11. Ground substance of the cartilaginous model (gs) is attacked by a macrophage before the adhesion proper. Minute vesicular structures ( $v$ ) and ground substance with collagen fibrils $(\leftarrow)$ serve to evidence that the ground substance is being solubilized. The nuclear envelope forms 
conspicuous invaginations, the cytoplasm contains large mitochondria (M), usually with electron empty centres. In perinuclear area, the Golgi complex is conspicuous ( $G$ ), cytoplasm contains somewhat smaller amount of granular endoplasmic reticulum (E) and vesicles (v) enveloped by a smooth membrane. Lysosomes $(\mathrm{L})$ and phagosomes $(\mathrm{Ph})$ containing not only granular but also fibrillar $(\leftarrow)$ material.

Fetus, $246 \mathrm{~d}, \times 10500$.

Fig. 12. Cytoplasmic pseudopodia penetrate into the ground substance, they segregate small fragments (gs) which are then phagocytized by a macrophage. The Golgi complex (G) forms large fields in the entire perinuclear area of cytoplasm. Some vesicles contain intravesicular inclusions $(\leftarrow)$ with own membranes. On the surface of the cytoplasmic membrane extrusion of the contents of vesicular structures $(\leftarrow)$ into the extracellular space towards the mineralized ground substance may be observed.

Fetus, $246 \mathrm{~d}, \times 9000$.

Fig. 13. Morphologically differring plasmatic pseudopodia of a macrophage penetrate into the ground substance of the cartilage, separate the individual particles of the originally compact trabecular surface. In the ground substance dense granules are visible $(\leftarrow)$. The clastic activity of macrophages results in separation of substrate fragments into the extracellular space where they are phagocytized or attacked by enzyme activity of clastic cell elements $(\leftarrow)$.

Fetus, 246 d, $\times 16000$.

Fig. 14. Phagocytized fragments of the ground substance of the cartilage (gs) forming the contents of a phagosome in the area of deep invagination of the nuclear envelope. A horseshoe-shaped nucleus $(\mathrm{N})$ with two nucleoli (nc) of reticular type is connected with another nuclear segment (N) by nuclear mass. In the cytoplasm, free ribosomes in the form of polysomes are visible.

Fetus, $271 \mathrm{~d}$, $\times 16100$.

Fig. 15. Free blood macrophages are functionally important especially in the postnatal period of ossification in which they play a paramount role in degradation of the ground substance and disintegrated structures of chondrocytes. After impairment of the transverse septum they are in direct contact with degenerated hypertrophied chondrocyte $(\mathrm{Hch})$. In the lacunar space blood plasma (p) and remains of the microfibrillar network appear. Fine collagen fibrils $(\leftarrow)$ present remains of the organic component of the transverse septum. By activity of macrophages fragments of the ground substance are being removed (gs). Large phagosomes ( $\mathrm{Ph}$ ) in the cytoplasm with granular material serve to support this finding. On the right hand side of the picture an osteoblast $(\mathrm{Ob})$ in initial secretory phase may be seen; it synthesizes the organic matrix and apposes it to the trabecular surface.

Cattle, 3 yr, 8500 .

Fig. 16. A group of free blood macrophages (Mf) in intimate contract with a hypertrophied chondrocyte (Hch) in the cytoplasm of which numerous glycogen $(\mathrm{g})$ granules are forming deposits. Pseudopodia begin to penetrate into the chondrocyte and phagocytize cellular structures $(\leftarrow)$.

Cattle, 3 yr, $\times 12000$.

Fig. 17. Agglomeration of mononuclear clastic cells apposed to the surface of a ground matrix trabecula (gs). The trabeculae are covered with a dense lamina limitans (11) showing degradation of the inorganic substance of the ground matrix of the cartilage. Collagen fibrils $(\leftarrow)$ are visible between the cytoplasmic membrane and trabecular surface.

Calf, $65 \mathrm{~d}, \times 6000$.

Fig. 18. A dense lamina limitans covering the trabecular surface is formed by collagen fibrils with conspicuous transverse periodicity $(\leftarrow)$. By cellular effects on the ground matrix (gs) solubilization of the inorganic substance occurs followed by exposure of collagen fibrils. Small fragments of the ground substance (gs) are formed and they separate from the compact mass of the trabecula. By the clastic activity of cells not only superficial but also deeper portions of the trabecular ground substance (gs) are attacked.

Fetus, 246, d, $\times 16000$.

Fig. 19. Trabecular surface of the ground substance (gs) of the cartilage is lined by organic matrix composed of collagen fibrils (cf). These are phagocytized individually $(\leftarrow)$ by macrophages. Calf, $65 \mathrm{~d}, \times 12000$.

Fig. 20. Besides collagen fibrils (cf) minute fragments of the ground substance (gs) are phagocytized by macrophages. This finding is a strong support of the fact that resorption of the organic matrix takes place simultaneously with fragmentation of the ground substance of the cartilage. Calf, $65 \mathrm{~d}, \times 12000$. 


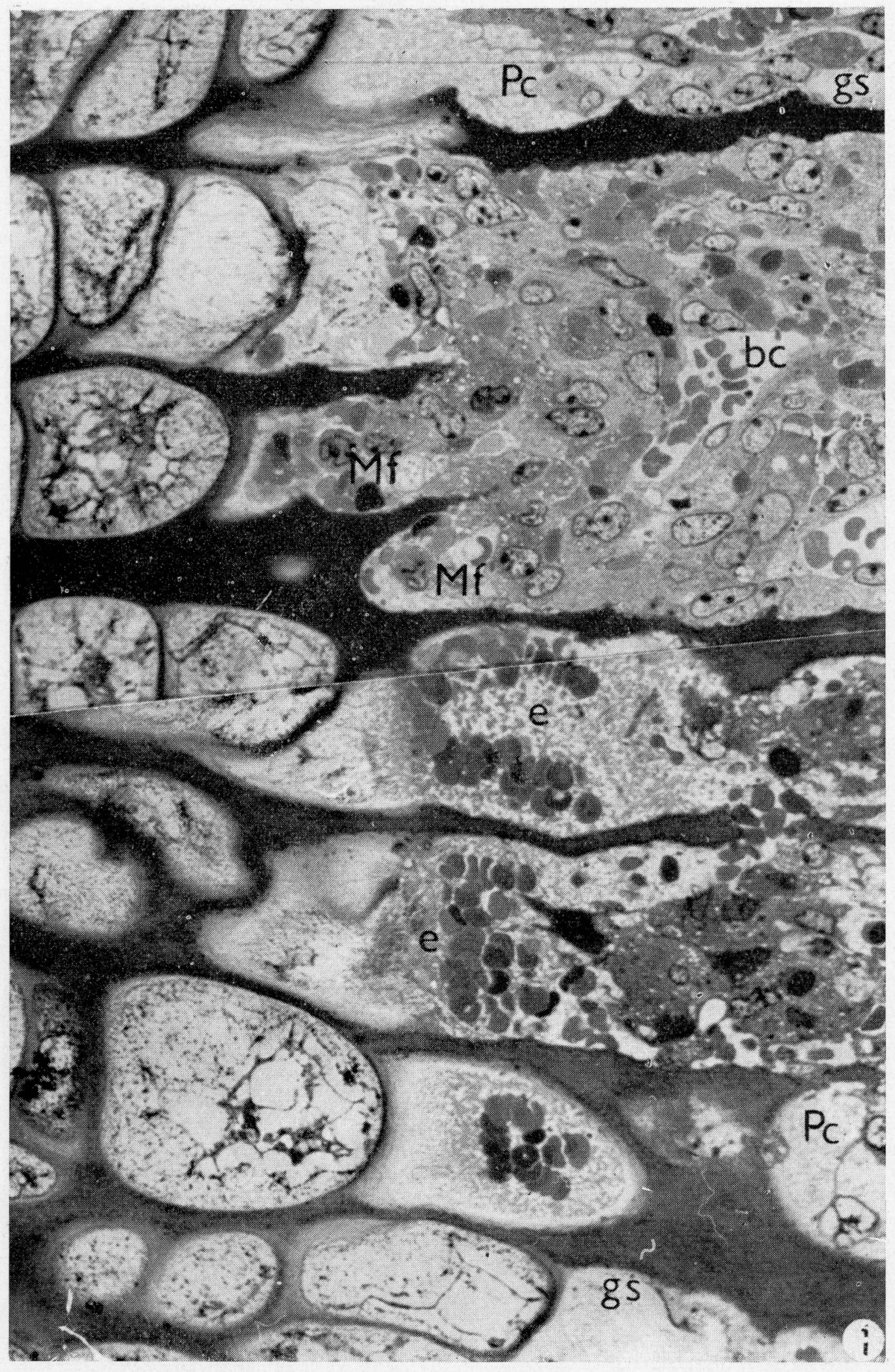




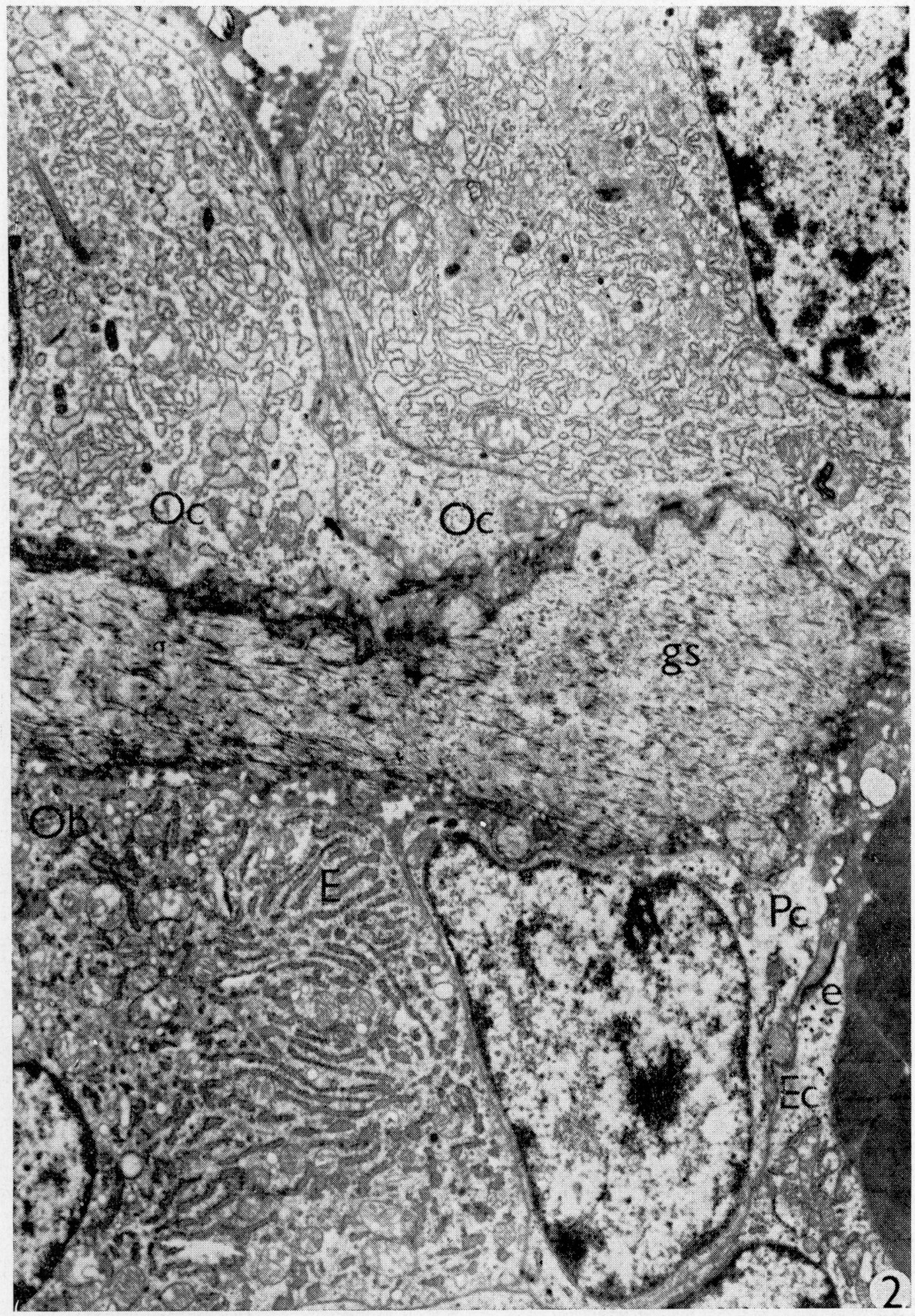




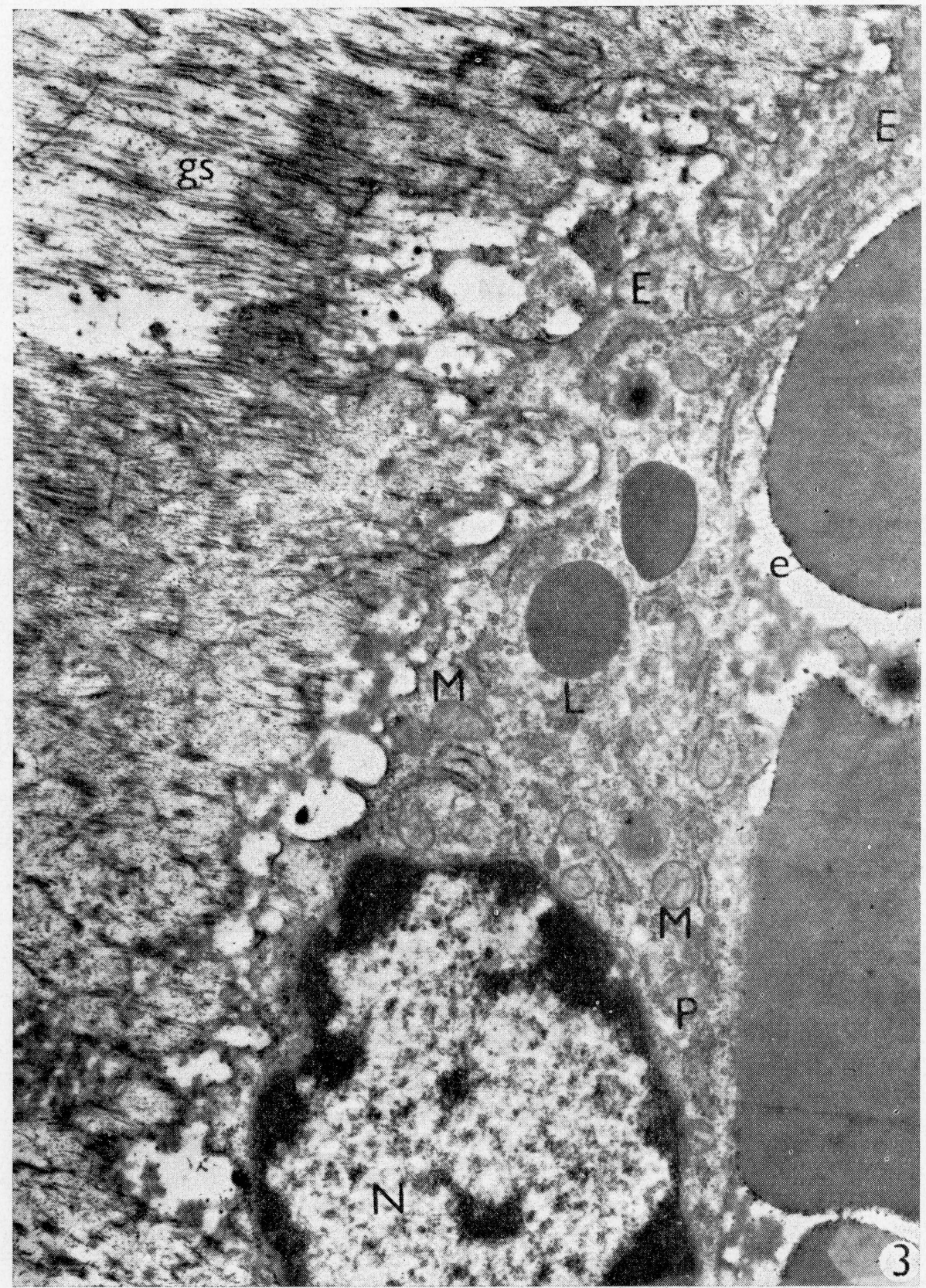




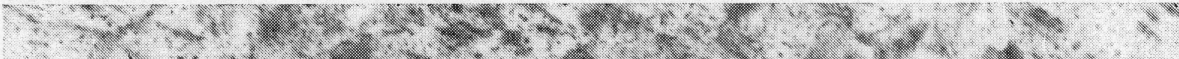

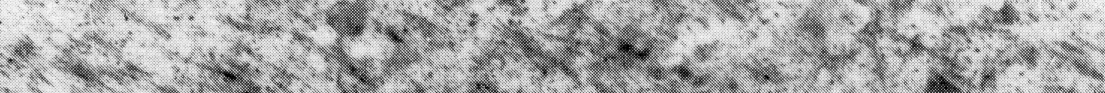

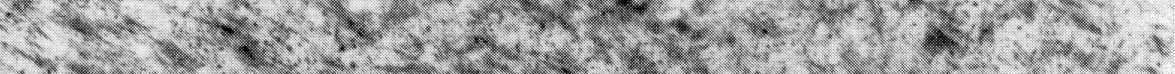

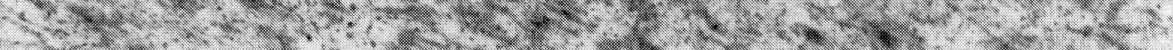

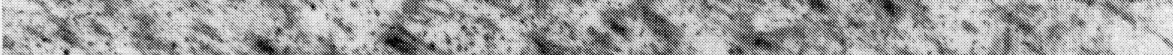

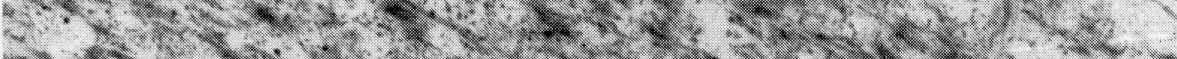
n.

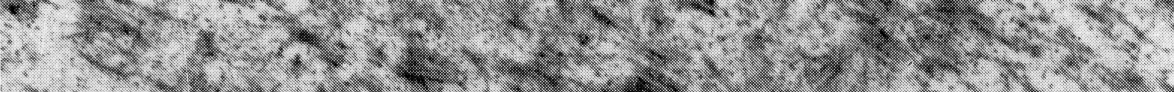

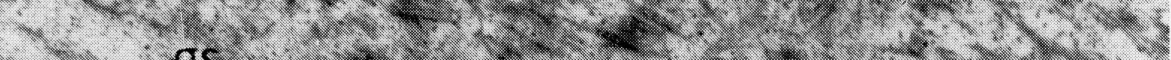
(2.2.

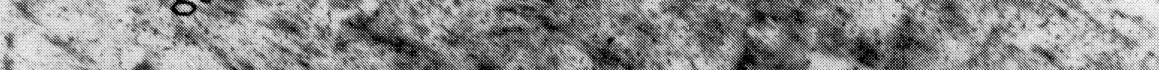

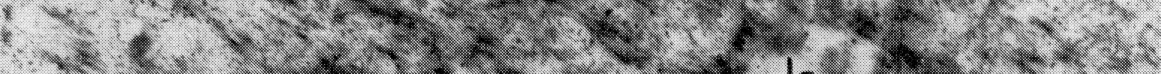

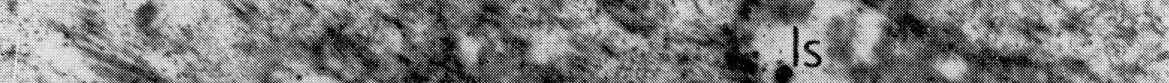

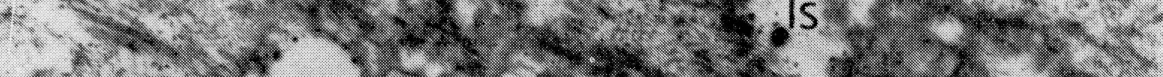

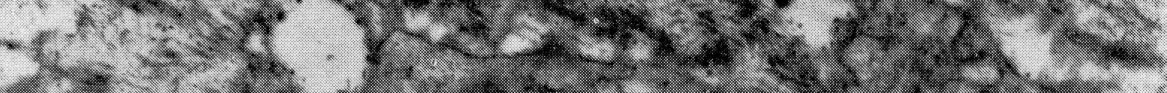

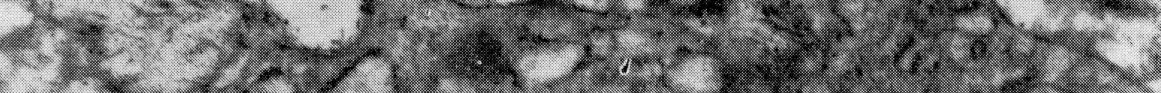

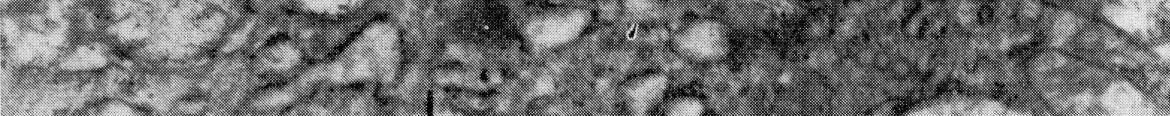

(2)

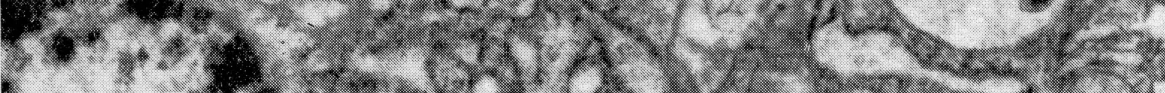

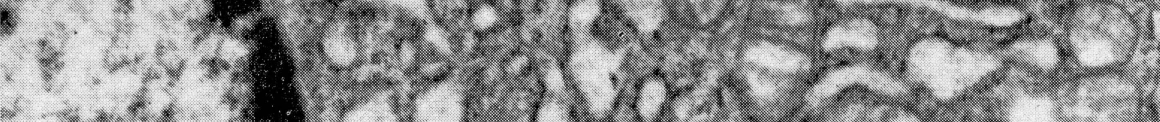

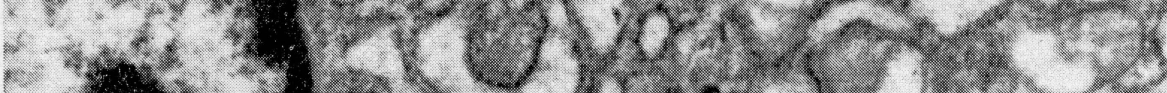

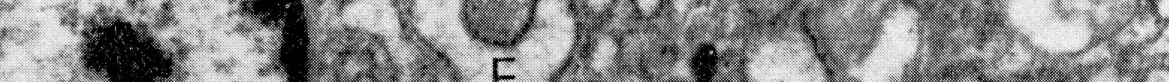

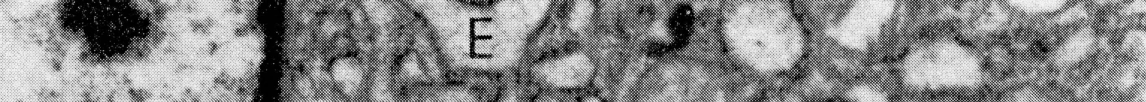

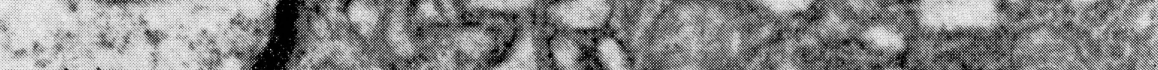

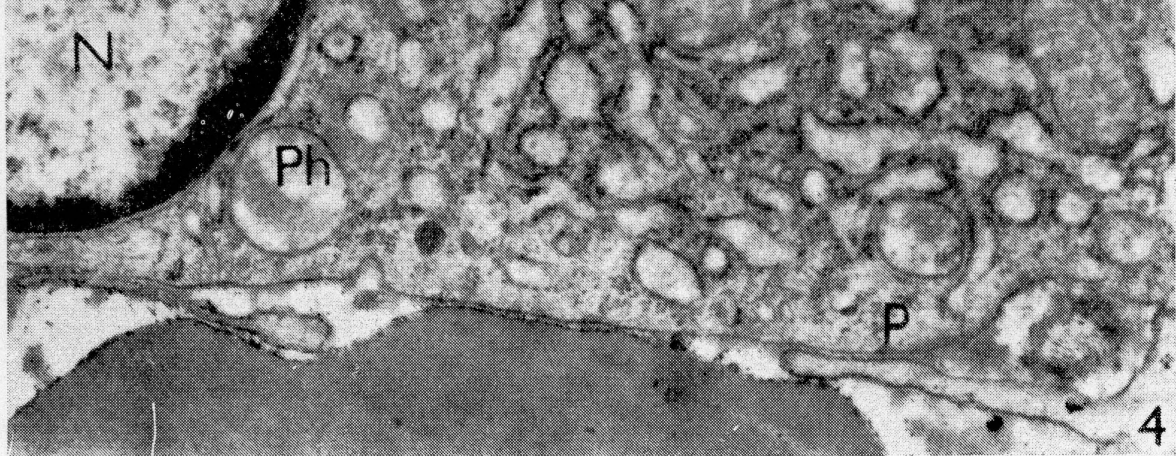



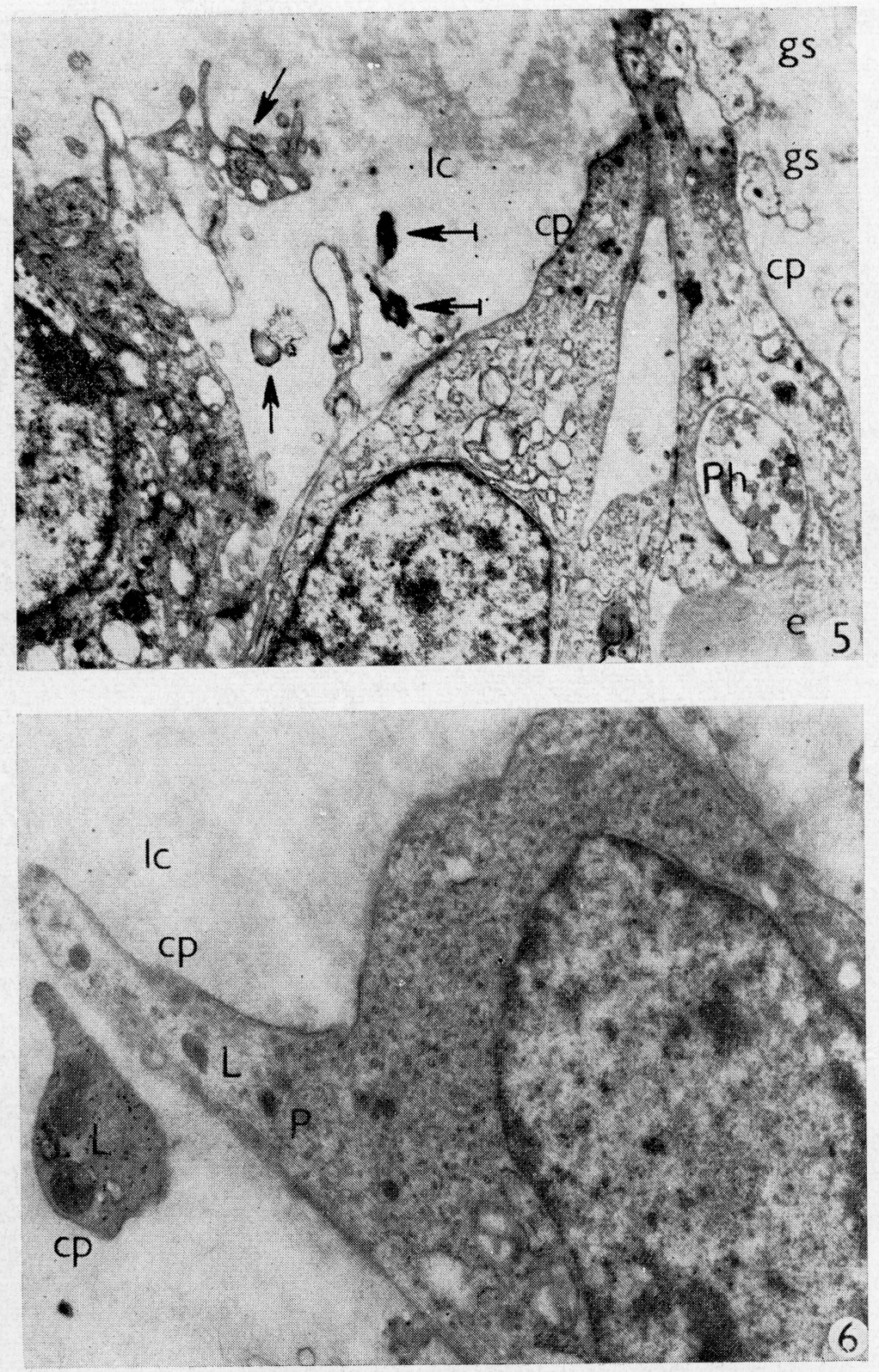


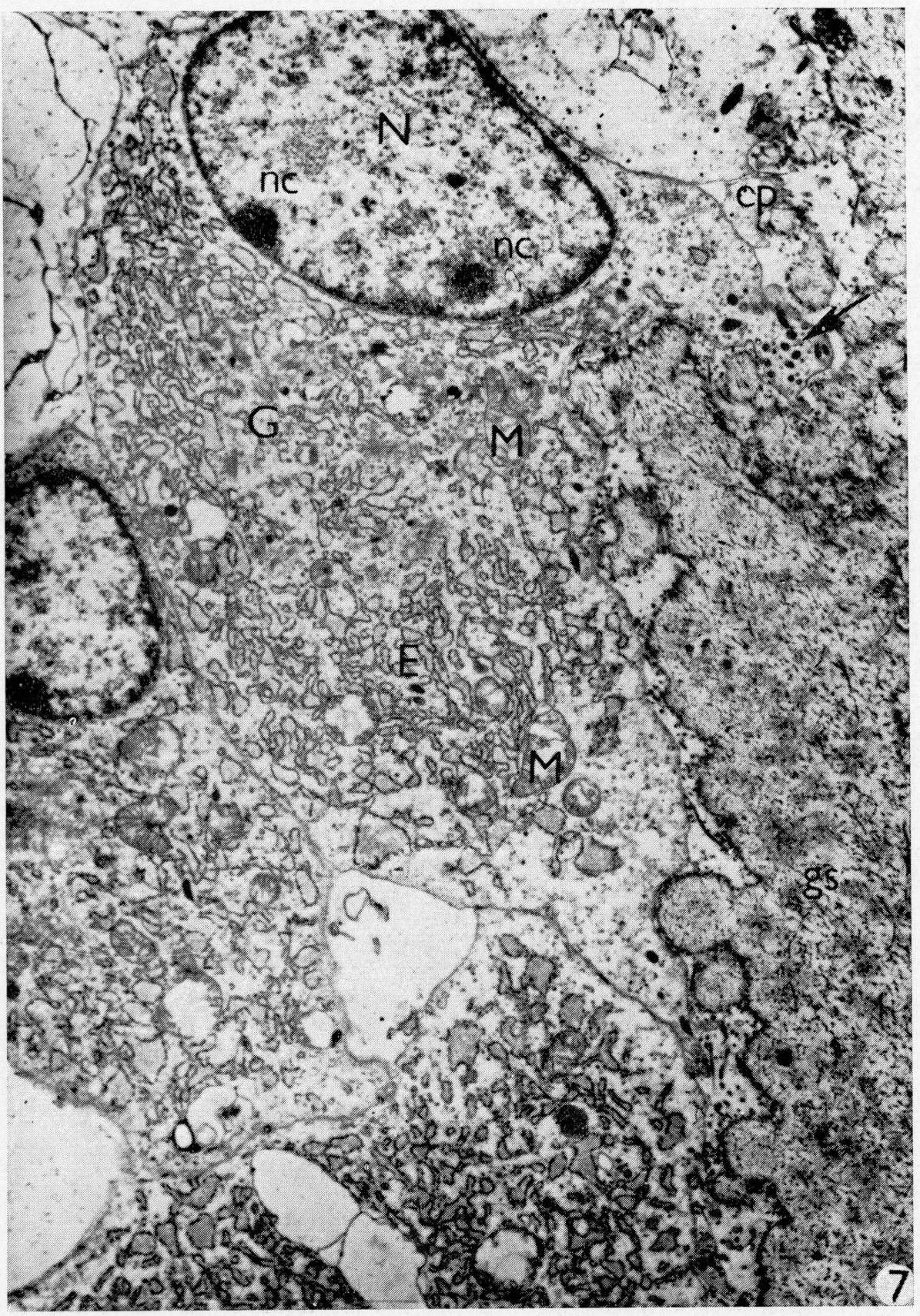




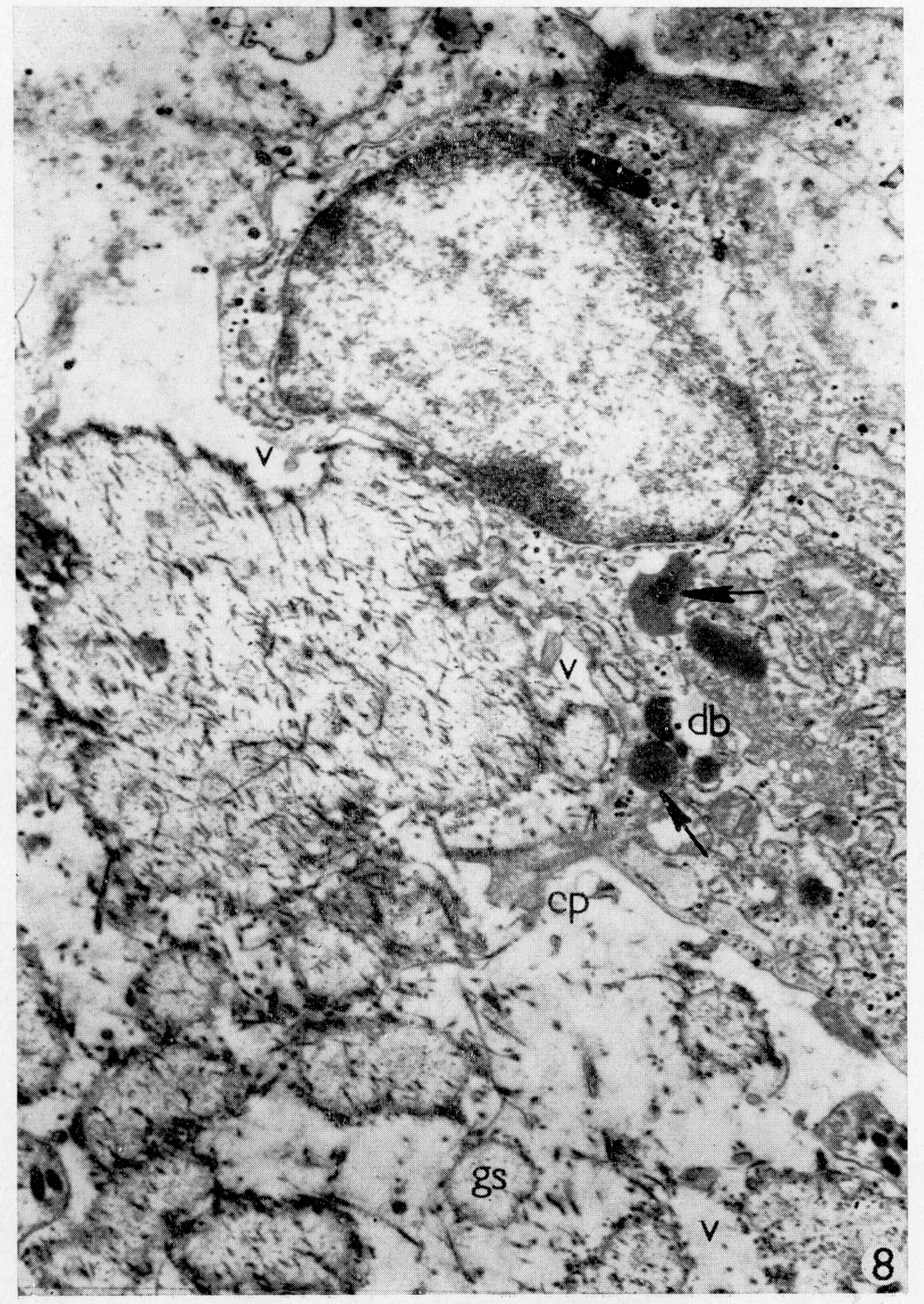



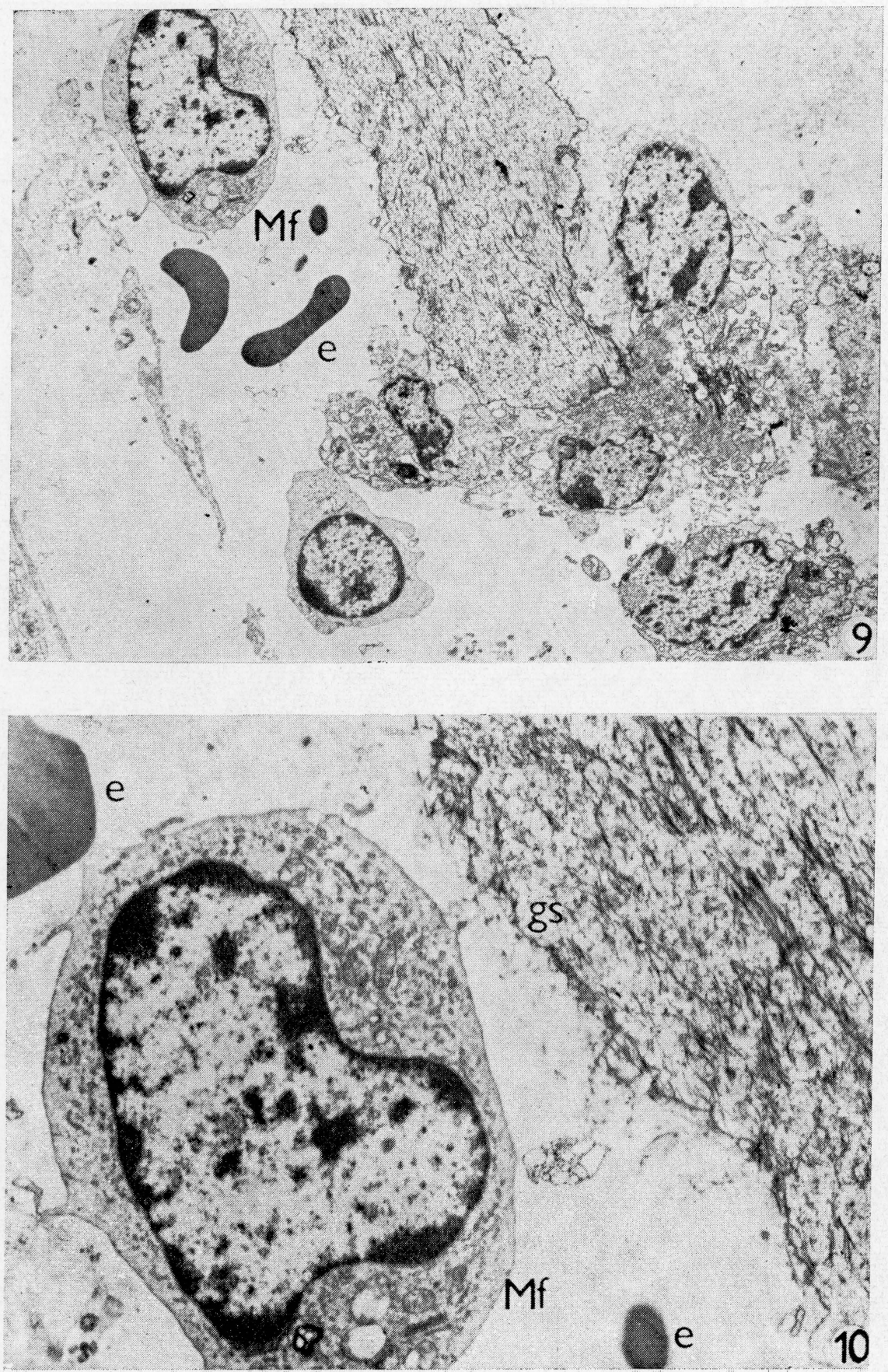

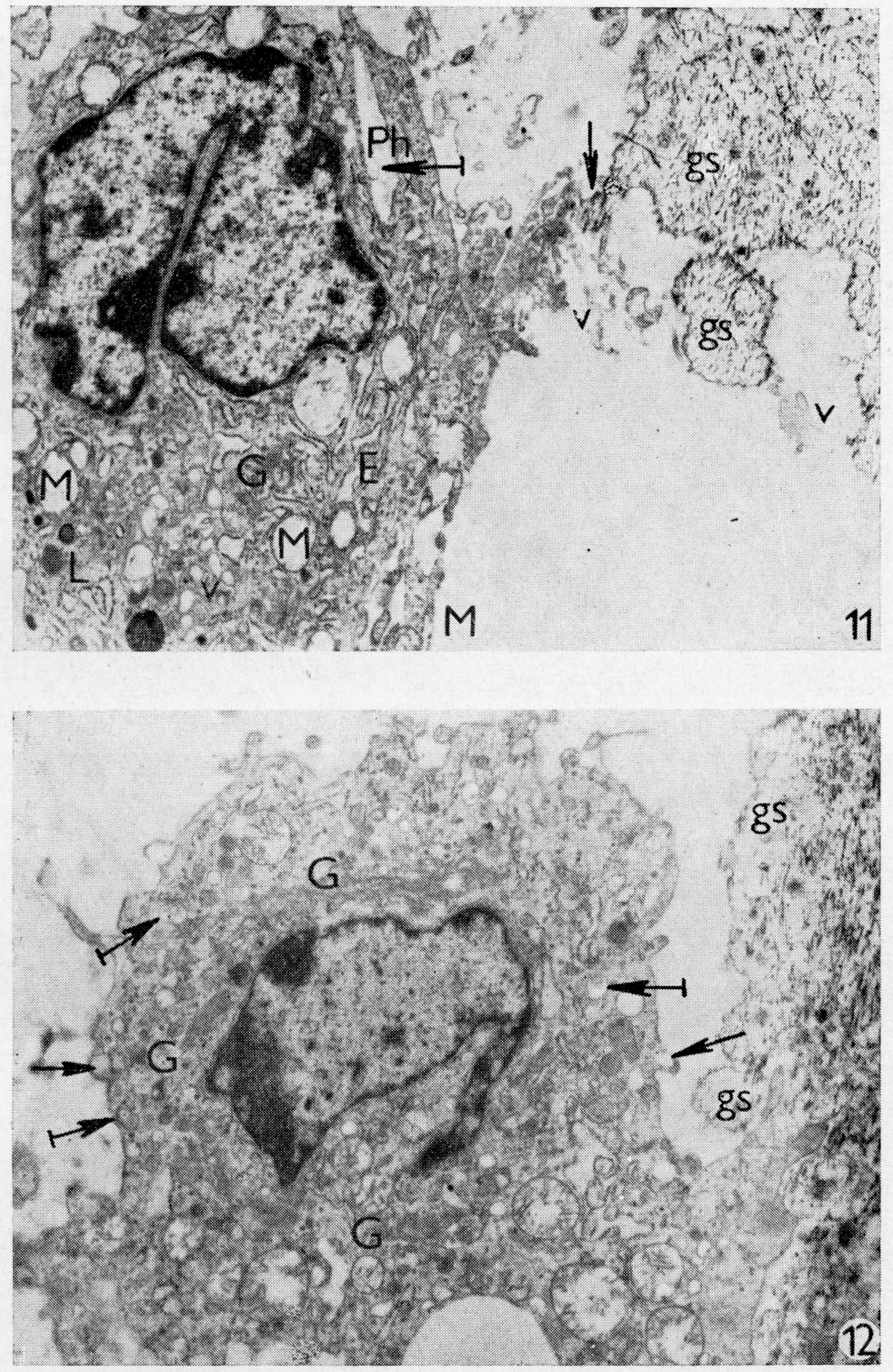

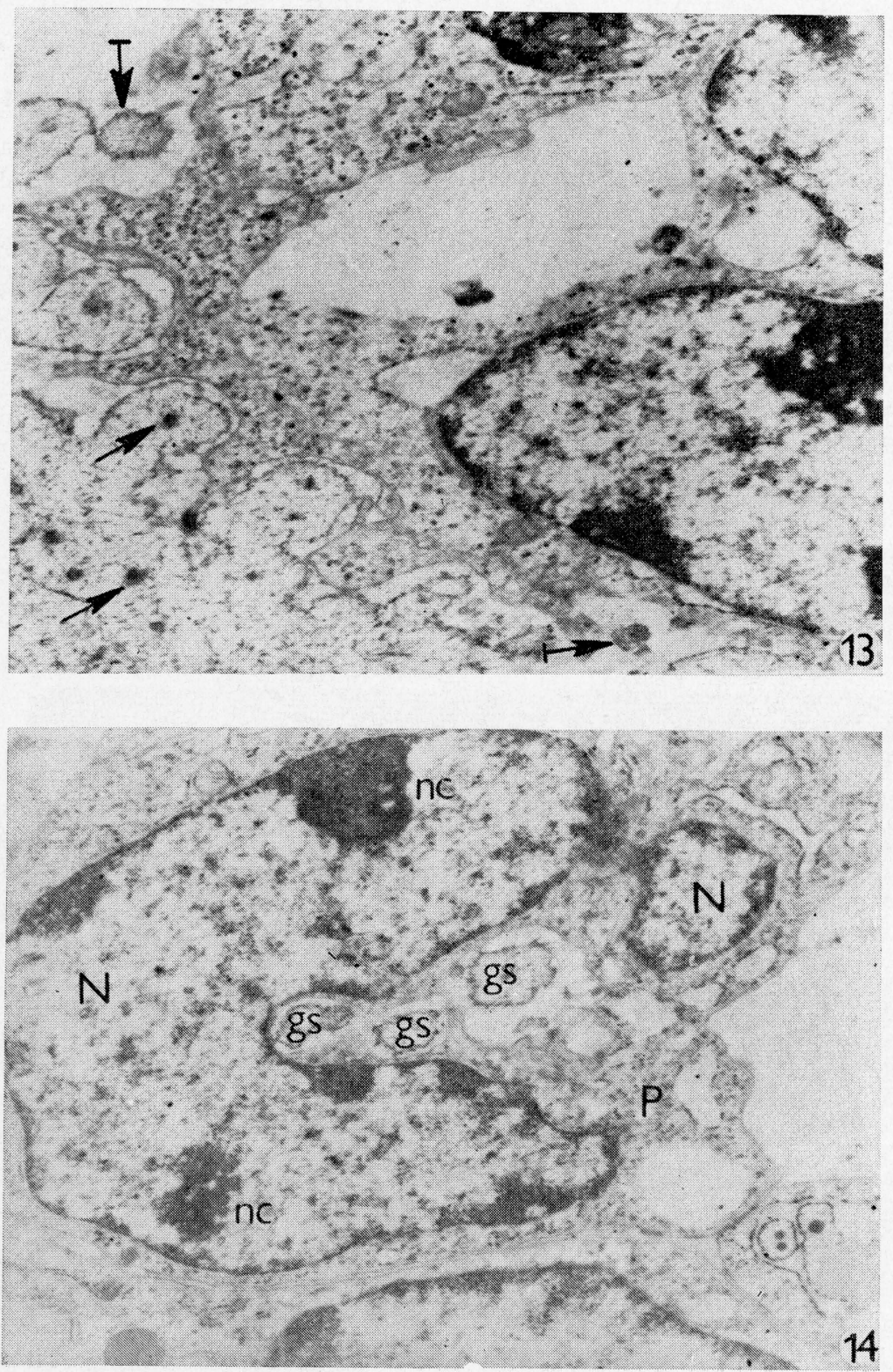


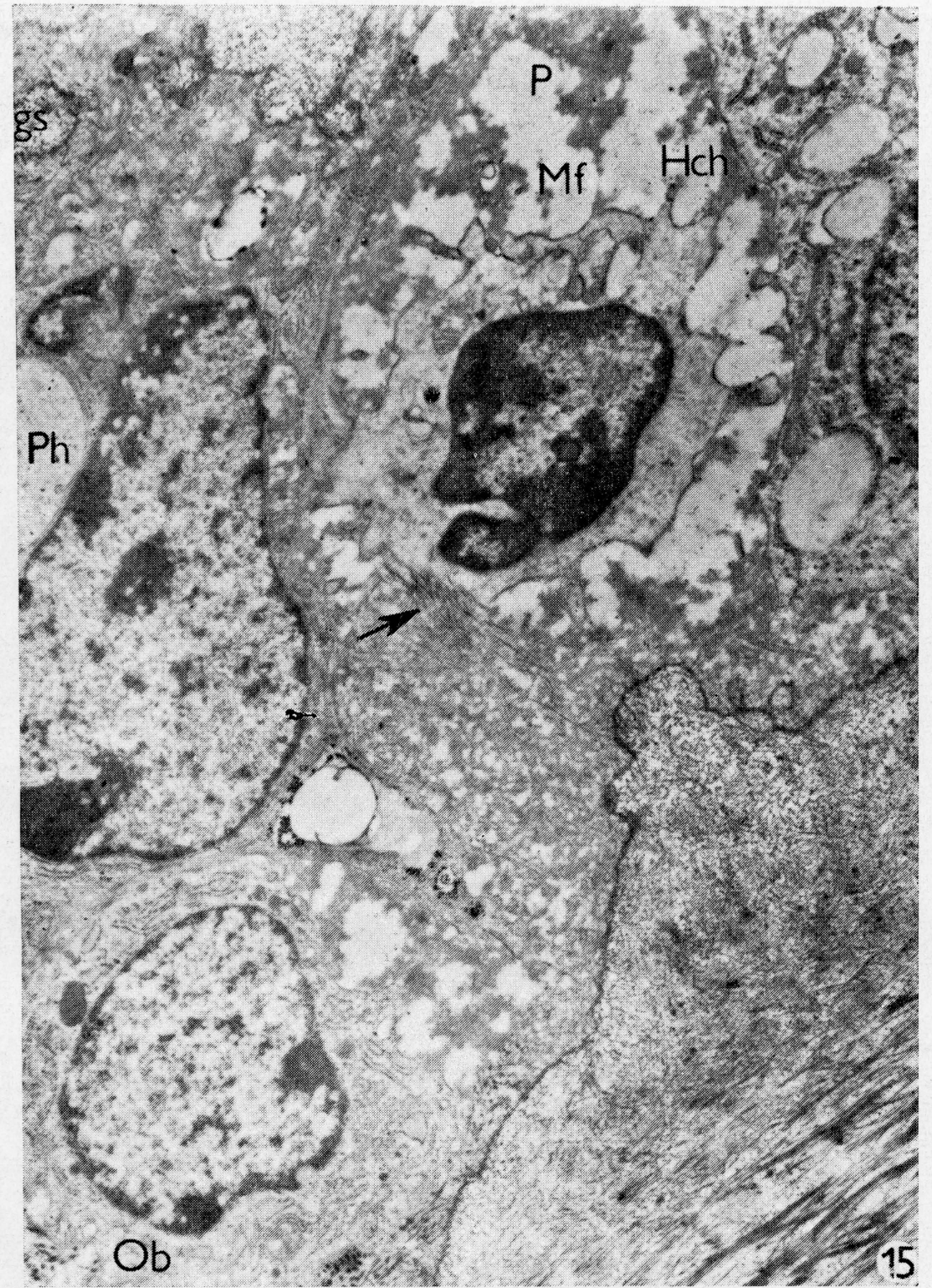




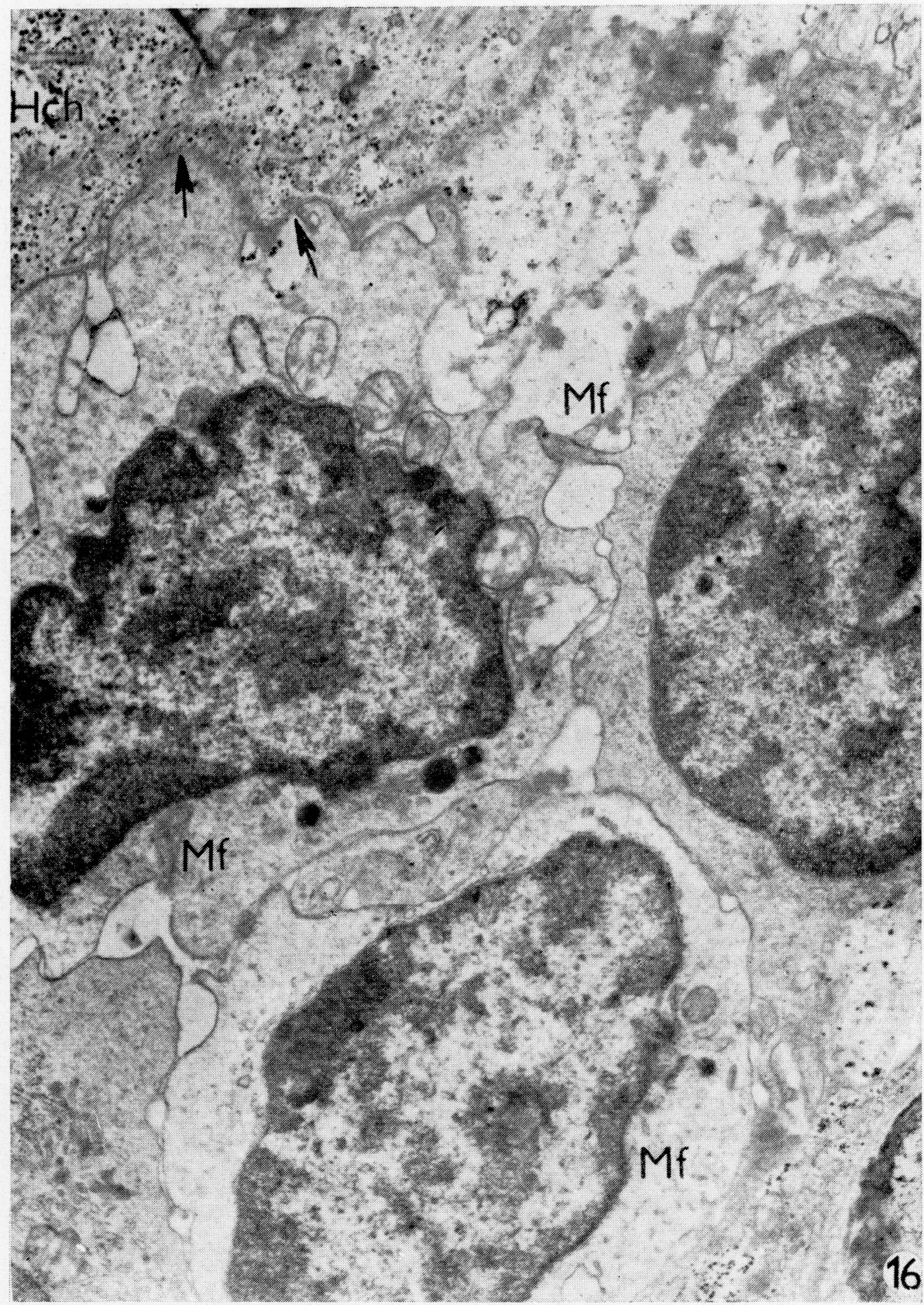



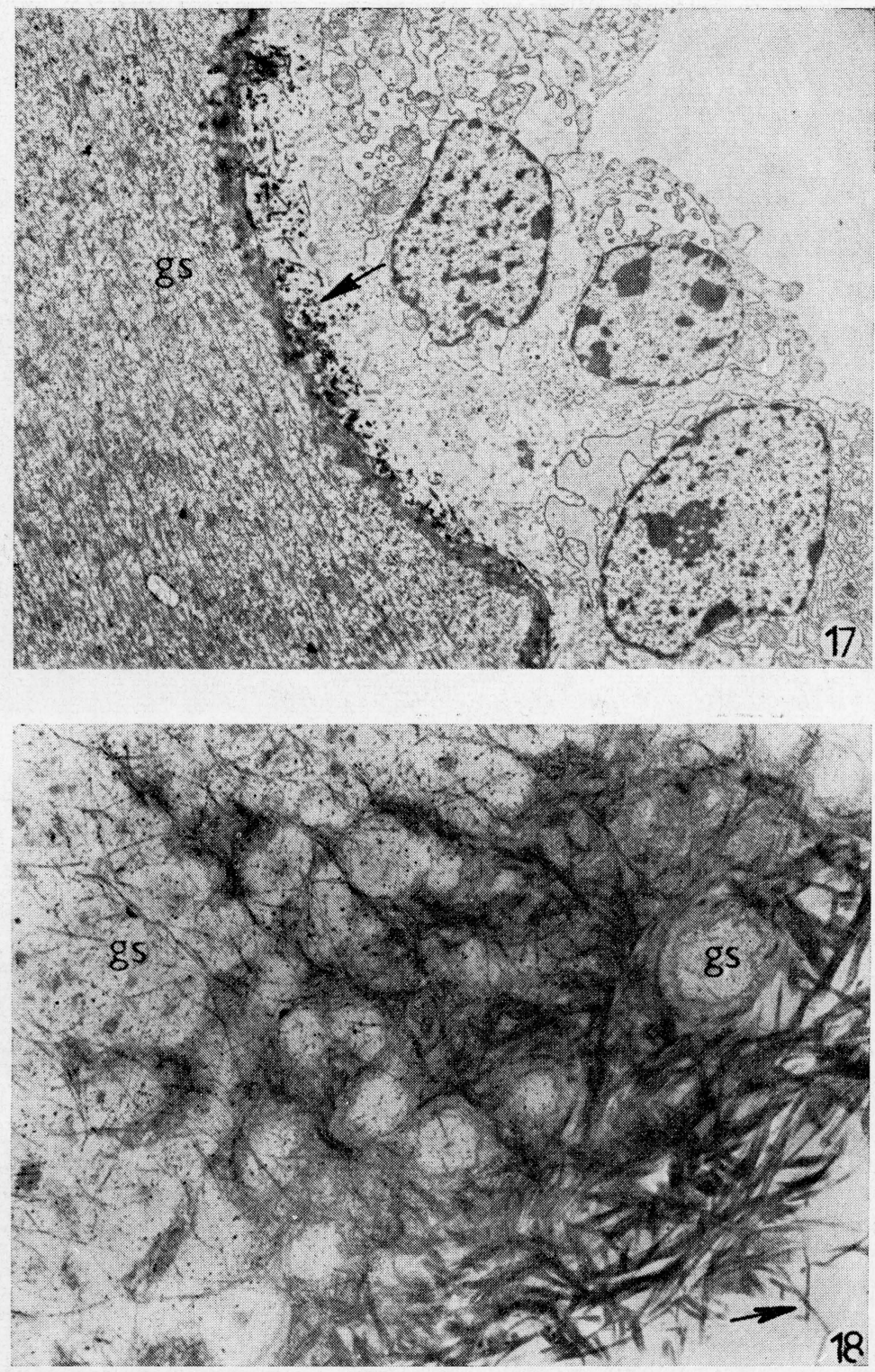

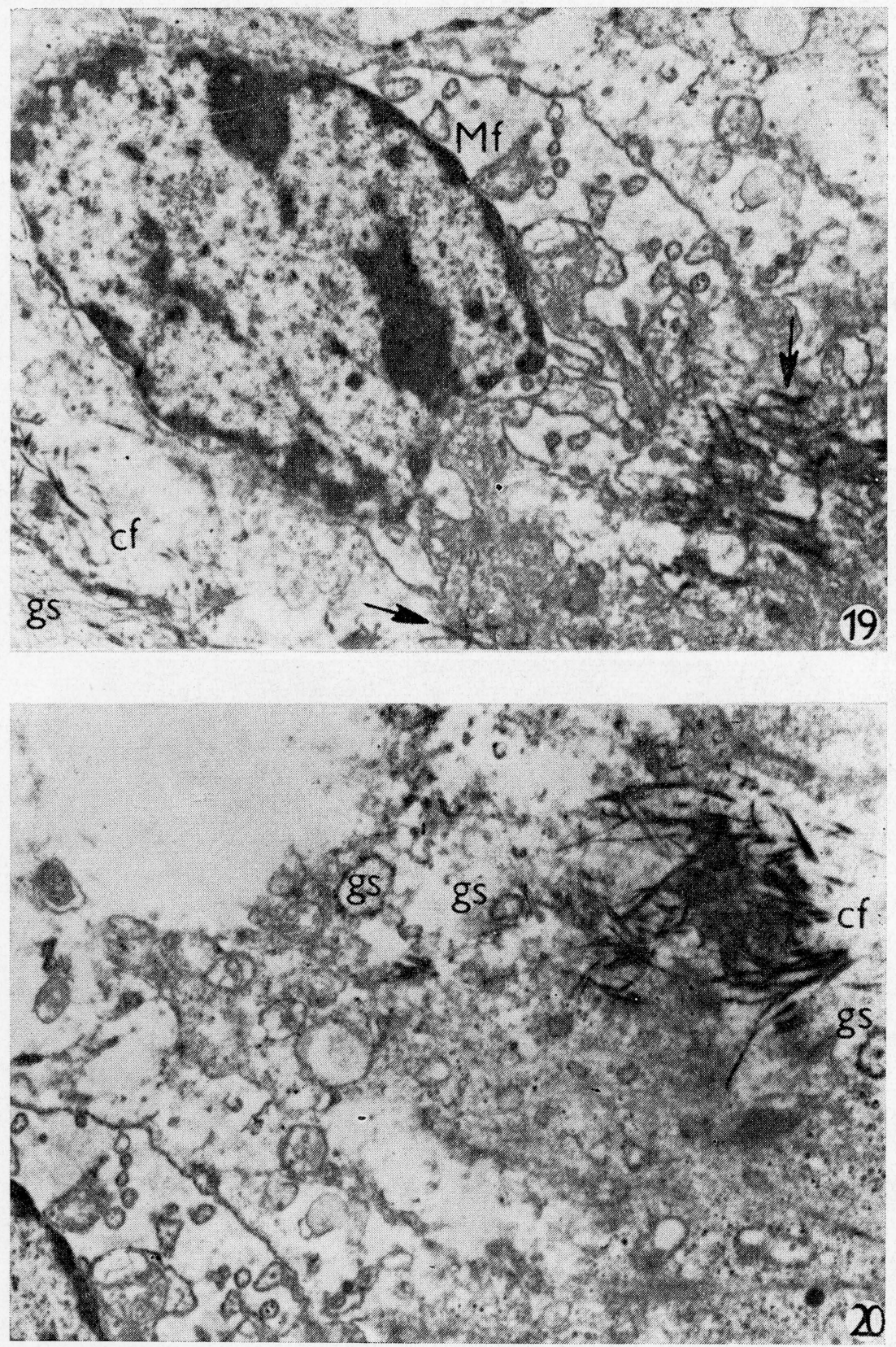


\section{References}

BÉLANGER, L. F.: Osteocytic osteolysis. Calcif. Tiss. Res., 4, 1969: 1-12.

BROOKES, M. - LANDON, D. N.: The juxta-epiphyseal vessels in the long bones of foetal rats. J. Bone Jt Surg., 46 B, 1964: 336-345.

CAMERON, D. A. - ROBINSON, R. A.: The presence of crystals in the cytoplasm of large cells adjacent to the sites of bone absorption. J. Bone Jt Surg., 40 A, 1958: 414-418.

CAMERON, D. A.: Erosion of the epiphysis of the rat tibia by capillaries. J. Bone Jt Surg., 43 B, 1961: 590-594.

CHAMBERS, T. J.: Resorption of bone by mouse peritoneal macrophages. J. Pathol., 135, 1981 : $295-301$.

ČERNÝ, H.: Úloha mononukleárních buněk na resorpci chrupavky v osifikaci. Morfologický kongres, Bratislava, 1982.

ČERNÝ, H.: Resorpce chrupavčitého modelu v enchondrální osifikaci. Scripta medica, Brno, 56, 1983: 46.

DUDLEY, M. R. - SPIRO, D.: The fine structure of bone cells. J. biophys. biochem. Cytol., 11, 1961: 627-661.

GARANT, P. R.: Collagen resorption by fibroblasts. A theory of fibroblastic maintenance of the periodontal ligament. J. Periodont., 47, 1976: 380-390.

HEERSCHE, J. N. M.: Mechanism of Osteoclastic Bone Resorption: A New Hypothesis. Calcif. Tiss. Res., 26, 1978: 81-84.

HORN, V.: Bone structures - Morphology and Function. Lék. fak. UJEP, Brno, 1979, 164 p. HORN, V. - DVOŘÁK, M.: Weitere Erfahrungen über die verschiedenen Formen der Osteoklasie. Z. Orthop., 118, 1980: 1-7.

IRVING, J. T. - HEELEY, J. D.: Resorption of bone collagen by multinucleated cells. Calcif. Tiss. Res., 6, 1970: 254-259.

JANDE, S. S. - BÉLANGER, L. F.: Electron microscopy of osteocytes and the pericellular matrix in rat trabecular bone. Calcif. Tiss. Res., 6, 1971; 280-289.

JANDE, S. S. - BÉLANGER, L. F.: The life cycle of the osteocyte. Clin. Orthop., 94, 1973: $281-305$.

LESTER, K. S. - ASH, M. M.: Ossification in adult Rat Mandibular Condyle - SEM of Chondroklasia. J. Ultrastruct. Res., 74, 1981: 46-58.

MUNDY, G. R. - ALTMAN, A. J. - GONDEK, M. D., BANDELIN, J. G. : Direct resorption of bone by human monocytes. Science, 196, 1977: 1109-1111.

OWEN, M.: Histogenesis of Bone Cells. Calcif. Tiss. Res., 25, 1978: 205-207.

RASMUSSEN, H. - BORDIER, P.: The Physiological and Cellular Basis of Metabolic Bone Disease. Williams and Wilkins Co., Baltimore, 1974: 364.

SCHENK, R. K. - SPIRO, D. - WIENER, J.: Cartilage resorption in the tibial epiphyseal plate of growing rats. J. Cell Biol., 34, 1967: 275-291.

SCHERFT, J. P.: The lamina limitans of the organic matrix of calcified cartilage and bone. J. Ultrastruct. Res., 38, 1972: $318-331$.

SCHOFIELD, B. H. - LEVIN, S. L. - DOTY, S. B.: Ultrastructure and Lysosomal Histochemistry of ia Rat Osteoclasts. Calcif. Tiss. Res., 14, 1974: 153-160.

SCOTT, B. L. - PEASE, D. C.: Electron microscopy of the epiphyseal apparatus. Anat. Rec., 126, 1956: 465-482.

SMITH, M. M. - PRIEST, N. D. - BLACKWOOD, H. J. J.: The lamina limitans in mineralizing cartilage. J. Anat., 118, 1974: 365-366.

TRUETA, J. - LITTLE, K.: The vascular contribution to osteogenesis. II. Studies with the electron microscope. J. Bone Jt Surg., 42 B, 1960: 367-376.

TRUETA, J.: The role of the vessels in osteogenesis. J. Bone Jt Surg., 45 B, 1963: 402-418. 